\title{
Feeding ecology of eastern North Pacific killer whales Orcinus orca from fatty acid, stable isotope, and organochlorine analyses of blubber biopsies
}

\author{
D. P. Herman ${ }^{1, *}$, D. G. Burrows ${ }^{1}$, P. R. Wade ${ }^{2}$, J. W. Durban ${ }^{2}$, C. O. Matkin ${ }^{3}$, \\ R. G. LeDuc ${ }^{4}$, L. G. Barrett-Lennard ${ }^{5}$, M. M. Krahn ${ }^{1}$ \\ ${ }^{1}$ NOAA Fisheries, Northwest Fisheries Science Center, 2725 Montlake Boulevard East, Seattle, Washington 98112, USA \\ ${ }^{2}$ NOAA Fisheries, Alaska Fisheries Science Center, 7600 Sand Point Way NE, Seattle, Washington 98115, USA \\ ${ }^{3}$ North Gulf Oceanic Society, PO Box 15244, Homer, Alaska 99603, USA \\ ${ }^{4}$ NOAA Fisheries, Southwest Fisheries Science Center, 8604 La Jolla Shores Drive, San Diego, California 92037, USA \\ ${ }^{5}$ Vancouver Aquarium Marine Science Centre, Box 3232, Vancouver, British Columbia V6B 3X8, Canada
}

\begin{abstract}
Blubber biopsy samples from eastern North Pacific killer whales Orcinus orca were analyzed for fatty acids, carbon and nitrogen stable isotopes and organochlorine contaminants. Fatty acid profiles were sufficiently distinct among the 3 reported ecotypes ('resident,' 'transient' or 'offshore') to enable individual animals to be correctly classified by ecotype and also by mitochondrial DNA (mtDNA) haplotype. Profiles of PCBs also enabled unambiguous classification of all 3 killer whale ecotypes, but stable isotope values lacked sufficient resolution. Fatty acid, stable isotope and PCB profiles of the resident and transient ecotypes were consistent with those expected for these whales based on their reported dietary preferences (fish for resident whales, marine mammals for transients). In addition, these ecotype profiles exhibited broad similarity across geographical regions, suggesting that the dietary specialization reported for resident and transient whales in the well-studied eastern North Pacific populations also extends to the less-studied killer whales in the western Gulf of Alaska and Aleutian Islands. Killer whales of the same ecotype were also grouped by region of sample collection. The mean stable isotope ratios of various regional groups differed considerably, suggesting that the prey preferences of these North Pacific killer whales may be both region and ecotype specific. Furthermore, 3 specific ecotypes of killer whales were found to have measured stable isotope values that were consistent with dietary preferences reported in the literature. Finally, although the offshore population had blubber fatty acid profiles implicating fish as its primary prey, contaminant and stable isotope results were equally congruent with predation on marine mammals.
\end{abstract}

KEY WORDS: Feeding ecology Killer whale $\cdot$ Biopsy sampling $\cdot$ Stable isotopes $\cdot$ Fatty acids · Organochlorines $\cdot$ Pollutants $\cdot$ Pacific Ocean

Resale or republication not permitted without written consent of the publisher

\section{INTRODUCTION}

Assessing the diet and trophic position of a top-level marine predator is important to the understanding of the ecology of marine food webs. For example, recent attention has focused on the possible role of predation by killer whales Orcinus orca in the population declines of several stocks of different marine mammal species in the western Gulf of Alaska, Aleutian Islands and the Bering Sea (Jefferson et al. 1991, Springer et al. 2003). Evaluating this hypothesis requires specific information on the diet of killer whales in this area. However, the application of traditional methods of diet analysis for marine predators has known biases and limitations. For example, observational data are typically limited to predation occurring at or near the ocean surface during spring and summer months and reveal little about the foraging habits of these animals below the surface or at other times of the year. In addition, stomach content analyses may be biased in favor 
of species having large masses of durable hard parts due to differential rates of digestion (Tollit et al. 1997). Furthermore, both of these methods provide only a snapshot of the most recent meal and may therefore not be representative of the typical long-term diet. These known biases have created a need to develop and employ alternative, indirect chemical analysis techniques that may more accurately reflect the longterm diet and that, equally importantly, can be obtained from biopsy sampling of free-ranging animals.

Among the indirect methods that assess the trophic position and dietary preferences of marine mammals from biopsy samples, fatty acid signature analysis of blubber (Iverson et al. 2004) and stable isotope signatures of ${ }^{13} \mathrm{C}$ and ${ }^{15} \mathrm{~N}$ in the epidermis (Gendron et al. 2001) are the most utilized. Fatty acid signature analysis has been used to study the diet of a number of marine mammal species, e.g. belugas Delphinapterus leucas (Dahl et al. 2000), and harbor seals Phoca vitulina richardsi (Iverson et al. 1997). Quantitative fatty acid signature analysis requires either that fatty acids from prey species be incorporated largely unmodified into the adipose tissue of the predator or that the effects of selective metabolism and biosynthesis by the predator be quantitatively accounted for by establishing calibration factors from captive feeding studies (Iverson et al. 2004). In addition, the inner blubber layer has been used preferentially because the fatty acid composition of the inner layer is generally believed to be more metabolically active and therefore reflects diet better than outer blubber (Olsen \& GrahlNielsen 2003). Thus, the application of this approach has been limited by the difficulty of obtaining biopsies of the inner blubber layers of free-ranging animals, and uncertainty associated with evaluating calibration factors. Nonetheless, fatty acid analyses at a more qualitative level may still prove to be an effective indirect tool for making inferences about diet.

Stable isotope ratios of nitrogen $\left({ }^{15} \mathrm{~N} /{ }^{14} \mathrm{~N}\right)$, and to a lesser extent carbon $\left({ }^{13} \mathrm{C} /{ }^{12} \mathrm{C}\right)$, show a stepwise enrichment with each increasing trophic level in the marine environment (DeNiro \& Epstein 1978, 1981, Hobson \& Welch 1992). Because these carbon and nitrogen isotope ratios reflect food consumed and assimilated, shifts in stable isotope ratios can be used to provide general information about the diet of a predator. Although used less frequently for dietary reconstructions, patterns of organochlorine (OC) contaminants have also been used to differentiate various marine mammal stocks, presumably as a result of differences in the OC composition of their respective prey (Muir et al. 1996).

Combining the results from 2 or more of these techniques increases the information gained. For example, Hooker et al. (2001) showed that fatty acid profiles and stable isotope compositions in biopsy samples - when used in combination - provided useful information about the diet of northern bottlenose whales Hyperoodon ampullatus. In addition, Fisk et al. (2002) demonstrated the utility of combining OC contaminant results with stable isotope data in assessing the feeding ecology of Greenland sharks Somniousus microcephalus. Because potential ambiguities exist in interpreting the results from each of these individual indirect methods of diet estimation, employing multiple independent chemical methods may provide more accurate results than those obtained from measurements using a single biometric.

In this study, blubber from biopsy samples was analysed for fatty acids, stable isotopes, and OC contaminants, and the results were used in combination to infer the prey preferences of North Pacific killer whales. These analyses were conducted across a broad range of North Pacific killer whale populations and regionally distinct groups, but emphasis was placed on killer whales from the Gulf of Alaska and the Aleutian Islands, about which little information is available. In other areas of the North Pacific, notably Prince William Sound, Southeast Alaska, British Columbia, and Washington State, 2 discrete 'ecotypes' of killer whales, termed 'residents' and 'transients', have been documented (Bigg 1982, Ford et al. 2000). These resident and transient whales differ in their genetics (Hoelzel et al. 1998), acoustics (Barrett-Lennard et al. 1996), morphology (Ford et al. 2000) and feeding ecology, with transients thought to prey only on marine mammals and residents thought to solely consume fish, principally salmon (Baird \& Dill 1995, Ford et al. 1998, Saulitis et al. 2000). Based on similar criteria, a third ecotype, termed 'offshores', has been proposed (Ford et al. 2000). The offshore whales have been primarily encountered in waters off the coast between California and SE Alaska and are found less frequently than resident and transient whales in near-shore coastal waters (Krahn et al. 2004a, M. Dahlheim, NOAA/National Marine Mammal Laboratory, Seattle, WA, unpubl. data 2004). Relatively few feeding observations have been made for the offshore type, but initial data suggest that their diet includes fish (Ford et al. 2000).

Due to a lack of direct observations of predation, it remains unclear whether the more remote killer whales found in the western Gulf of Alaska, Aleutian Islands, and Bering Sea exhibit the same dietary specializations that have been documented in the other regions of the eastern North Pacific. In this study, the combined fatty acid, stable isotope and OC contaminant analyses provided the first step in assessing the prey preferences of killer whales from these regions. The current results revealed that each of the killer whale ecotypes can be classified and distinguished 
from one another across broad geographical regions, thus increasing the understanding of the trophic dynamics and feeding ecology of these whales.

\section{MATERIALS AND METHODS}

Killer whales sampled (biopsy and necropsy). Blubber and epidermis samples were obtained from killer whales inhabiting a broad range of geographic regions of the eastern North Pacific Ocean from California to the central Aleutian Islands. These samples were analyzed for fatty acids, OC contaminants and stable isotope ratios (Table 1). In some instances, an insufficient quantity of tissue was available to allow all 3 types of analyses to be performed, resulting in incomplete datasets for some samples. Animals from both sexes and from various age groups were represented, with the majority of animals being adult males from Alaska collected during the 2002/2003 sampling years. In Table 1, sample collection dates are either embedded within their animal identifications (first 6 digits represent $\mathrm{yr} / \mathrm{mo} / \mathrm{d}$ ) or they appear in brackets. Gender was assigned genetically, where possible, or based on direct observations of whales in well-studied regions. In well-studied populations females were classified as 'juveniles' until they were judged to be of adult size or were documented to have reproduced ( 15 yr). Males were classified as 'juveniles' until the dorsal fin was judged to be 'sprouting' with the height/width ratio exceeding 1.4. This typically occurs at about age $15 \mathrm{yr}$. Thereafter, males were classified as 'sub-adults' until reaching physical maturity, when the dorsal fin height/width ratio equals that of a mature adult male $(\sim 1.7)$ at about age 21 yr (Olesiuk et al. 1990). With the exception of 6 animals, all samples were obtained from living whales using remote biopsy sampling techniques (Hoelzel et al. 1998, Barrett-Lennard 2000) and biopsy tips of various lengths (typically 2.0 to $3.0 \mathrm{~cm}$ ). In order to minimize potential sources of variability in the analytical results, all animals were targeted for sampling from the same body position, specifically the saddle-patch region on the dorsal flank just behind the dorsal fin. Because the blubber thickness of a healthy adult killer whale is typically 5 to $7 \mathrm{~cm}$, samples acquired using darts of these lengths will not penetrate the entire blubber column and therefore represent blubber tissue from the outer-most one-third to onehalf of the total blubber thickness. All biopsy samples were extracted from the retrieved biopsy darts aboard ship (typically within $1 \mathrm{~h}$ of acquisition) and placed in small, residue-free glass containers and stored frozen at $-20^{\circ} \mathrm{C}$. Upon reaching shore, the samples were transferred to a $-80^{\circ} \mathrm{C}$ freezer and stored until analyzed. In an attempt to standardize sample size, frozen biopsy samples were subjected to 2 lateral cuts. First, the epidermis was removed by cutting the sample 1 to $2 \mathrm{~mm}$ from the inside edge of the epidermis, and then a second lateral cut was made $2 \mathrm{~cm}$ from the inside edge of the epidermis (sample length $\approx 1.8 \mathrm{~cm}$ ). Stranded whales CA189, L60, and ATx were necropsied and full-blubber depth samples were collected $(0$ to $2 \mathrm{~cm}, 2$ to $4 \mathrm{~cm},>4 \mathrm{~cm}$ ) and analyzed for fatty acids and OC contaminants as reported by Krahn et al. (2004b). For direct comparisons to biopsy samples, unless otherwise indicated, only the 0 to $2 \mathrm{~cm}$ necropsy sub-samples for the stranded whales were included in the statistical analyses.

Killer whale group structure. In addition to traditional demographic data, all whales have been classified in Table 1 as belonging to 1 of the 3 ecotypes (i.e. 'residents', 'transients' and 'offshores') based on mitochondrial DNA (mtDNA) haplotype identity (BarrettLennard 2000). Although the offshore whales have only a single mtDNA haplotype (OFF), multiple haplotypes exist for residents (designated as SR, NR, and NEWR) and for transients (designated as AT1, GAT1, GAT2, WCT and NEWT). These mtDNA analyses indicate that the 3 killer whale ecotypes are distinct, but differences in mtDNA haplotypes alone are insufficient to denote discrete genetic populations within these ecotypes. In the absence of more detailed information about population structure through microsatellite DNA analyses, all killer whales of each ecotype have been grouped by geographical collection region in this study (Table 1). This allows examination of regional-specific dietary preferences, but these differences may not necessarily reflect differences among discrete populations. However, the offshore killer whales from the Gulf of Alaska and the Aleutian Islands have been combined into a single 'Alaska' group, because they share individuals, as evidenced by photo-identification resightings of individuals between these 2 regions ( $M$. Dahlheim unpubl. data 2004). Furthermore, photo-identification matches have also been recorded between offshore whales from the Bering Sea and those in British Columbia and California, indicating that some of these whales move over large areas of the Pacific Ocean and may function as 1 population (M. Dahlheim unpubl. data 2004). Although some researchers have noted that the terms 'residents', 'transients', and 'offshores' are misnomers (Baird \& Dill 1995), this manuscript will follow the recommendations of a recent workshop on the taxonomy of cetaceans (Reeves et al. 2004) and continue to use these widely recognized terms 'pending nomenclatural clarification'.

Fatty acid analyses. Fatty acid concentrations were determined for killer whale samples (necropsy and biopsy) as reported by Krahn et al. (2004b). Briefly, the 
Table 1. Orcinus orca. Collection locations, ecotypes and mtDNA haplotypes analyzed for fatty acids (FA), stable isotopes (SI), and organochlorines (OCs). B: biopsy; N: necropsy; Off: offshore; Res: resident; Trans: transient; Ad: adult; Juv: juvenile; Y: yearling; Neo: neonate. Ant s: anterior; Cent s: central; Post s: posterior body positions sampled relative to the saddle-patch area, respectively

\begin{tabular}{|c|c|c|c|c|c|c|c|c|c|c|c|}
\hline \multirow{2}{*}{$\begin{array}{l}\text { Sample } \\
\text { no. }\end{array}$} & \multicolumn{3}{|c|}{ Analyses $^{\mathrm{a}}$} & \multirow{2}{*}{$\begin{array}{c}\text { Animal } \\
\text { identification }^{\mathrm{b}}\end{array}$} & \multirow{2}{*}{$\begin{array}{l}\text { Sample } \\
\text { type }\end{array}$} & \multirow[t]{2}{*}{ Ecotype } & \multirow[t]{2}{*}{ Sex } & \multirow[t]{2}{*}{$\mathrm{Age}^{\mathrm{c}}$} & \multirow[t]{2}{*}{ Region $^{\mathrm{d}}$} & \multirow{2}{*}{$\begin{array}{l}\text { Collection } \\
\text { site }\end{array}$} & \multirow[t]{2}{*}{ Haplotype } \\
\hline & FA & & & & & & & & & & \\
\hline 1 & $\mathrm{x}$ & $\mathrm{x}$ & $\mathrm{x}$ & AM010726-01 & B & Off & $\mathrm{M}$ & Ad & Alaska & Trinity Is. & OFF \\
\hline 3 & $\mathrm{x}$ & $\mathrm{x}$ & $\mathrm{x}$ & СР030703-01 & B & Off & M & $\mathrm{Ad}$ & Alaska & Unalaska Is. & OFF \\
\hline 4 & $\mathrm{x}$ & & & AH020611-01 & B & Off & M & Ad & Alaska & Unalaska Is. & OFF \\
\hline 5 & $\mathrm{x}$ & $\mathrm{x}$ & & AM010725-02 & B & Res & M & Ad & Gulf of Alaska & Trinity Is. & NR \\
\hline 8 & $\mathrm{x}$ & & & AB-24 [1998] & B & Res & M & Ad & Gulf of Alaska & Prince William Sd & NR \\
\hline 9 & $\mathrm{x}$ & & & AB-10 [1998] & B & Res & $\mathrm{F}$ & Ad & Gulf of Alaska & Prince William Sd & NR \\
\hline 10 & $\mathrm{x}$ & $\mathrm{x}$ & $\mathrm{x}$ & СР020717-02 & B & Res & $\mathrm{F}$ & ? & C. Aleutian Is. & Samalga Pass & NR \\
\hline 11 & $\mathrm{x}$ & $\mathrm{x}$ & & СР020820-01 & B & Res & $\mathrm{F}$ & ? & Gulf of Alaska & Shelikof Strait & NR \\
\hline 12 & $\mathrm{x}$ & $\mathrm{x}$ & $\mathrm{x}$ & AH020527-01 & B & Res & $\mathrm{M}$ & Ad & C. Aleutian Is. & Amlia Is. & SR \\
\hline 13 & $\mathrm{x}$ & $\mathrm{x}$ & $\mathrm{x}$ & AH020527-02 & B & Res & $\mathrm{M}$ & Ad & C. Aleutian Is. & Amlia Is. & SR \\
\hline 14 & $\mathrm{x}$ & $\mathrm{x}$ & $\mathrm{x}$ & СР030706-01 & B & Res & $\mathrm{M}$ & Ad & E. Aleutian Is. & Unalaska Is. & NR \\
\hline 19 & $\mathrm{x}$ & $\mathrm{x}$ & $\mathrm{x}$ & СР030710-04 & B & Res & $\mathrm{F}$ & Juv & C. Aleutian Is. & Seguam Is. & SR \\
\hline 20 & $\mathrm{x}$ & $\mathrm{x}$ & $\mathrm{x}$ & СР030710-05 & B & Res & $\mathrm{M}$ & Ad & C. Aleutian Is. & Seguam Is. & NR \\
\hline 21 & $\mathrm{x}$ & $\mathrm{x}$ & $\mathrm{x}$ & СР030710-07 & B & Res & $\mathrm{M}$ & Sub-Ad & C. Aleutian Is. & Seguam Is. & SR \\
\hline 22 & $\mathrm{x}$ & $\mathrm{x}$ & $\mathrm{x}$ & СР030711-01 & B & Res & $\mathrm{F}$ & Ad & C. Aleutian Is. & Seguam Is. & SR \\
\hline 23 & $\mathrm{x}$ & $\mathrm{x}$ & $\mathrm{x}$ & СР030715-01 & B & Res & $\mathrm{M}$ & Ad & C. Aleutian Is. & Adak Is. & SR \\
\hline 24 & $\mathrm{x}$ & $\mathrm{x}$ & $\mathrm{x}$ & СР030721-01 & B & Res & $\mathrm{M}$ & Sub-Ad & E. Aleutian Is. & Unalaska Is. & NR \\
\hline 25 & $\mathrm{x}$ & $\mathrm{x}$ & $\mathrm{x}$ & СР030721-02 & B & Res & $\mathrm{M}$ & Ad & E. Aleutian Is. & Unalaska Is. & NR \\
\hline 26 & $\mathrm{x}$ & $\mathrm{x}$ & $\mathrm{x}$ & СР030721-03 & B & Res & $\mathrm{M}$ & Ad & E. Aleutian Is. & Unalaska Is. & NR \\
\hline 27 & $\mathrm{x}$ & $\mathrm{x}$ & $\mathrm{x}$ & СР030721-04 & B & Res & $\mathrm{M}$ & Ad & E. Aleutian Is. & Unalaska Is. & NR \\
\hline 28 & $\mathrm{x}$ & $\mathrm{x}$ & $\mathrm{x}$ & СР030721-05 & B & Res & $\mathrm{M}$ & Ad & E. Aleutian Is. & Unalaska Is. & NR \\
\hline 29 & $\mathrm{x}$ & $\mathrm{x}$ & $\mathrm{x}$ & СР030721-06 & B & Res & $\mathrm{M}$ & Ad & E. Aleutian Is. & Unalaska Is. & NR \\
\hline 30 & $\mathrm{x}$ & $\mathrm{x}$ & $\mathrm{x}$ & СР030806-01 & B & Res & $\mathrm{F}$ & Ad & Gulf of Alaska & Marmot Is. & NR \\
\hline 31 & $\mathrm{x}$ & $\mathrm{x}$ & $\mathrm{x}$ & СР030806-02 & B & Res & $\mathrm{F}$ & Ad & Gulf of Alaska & Marmot Is. & NR \\
\hline 40 & $\mathrm{x}$ & $\mathrm{x}$ & & AM010803-01 & B & Trans & $\mathrm{M}$ & $\mathrm{Ad}$ & E. Aleutian Is. & Unimak Pass & GAT1 \\
\hline 41 & $\mathrm{x}$ & & & T-102 [1999] & B & Trans & $\mathrm{M}$ & Juv & Southeast Alaska & Glacier Bay & GAT \\
\hline 42 & $\mathrm{x}$ & & & AT-6 [1999] & B & Trans & $\mathrm{M}$ & $\mathrm{Ad}$ & Prince William Sd & Kenai Fjords & AT1 \\
\hline 43 & $\mathrm{x}$ & $\mathrm{x}$ & $\mathrm{x}$ & AH020618-04 & B & Trans & $\mathrm{M}$ & Ad & E. Aleutian Is. & Unimak Is. & GAT \\
\hline 44 & $\mathrm{x}$ & & $\mathrm{x}$ & AH020618-05 & B & Trans & $\mathrm{M}$ & Ad & E. Aleutian Is. & Unimak Is. & GAT2 \\
\hline 45 & $\mathrm{x}$ & $\mathrm{x}$ & $\mathrm{x}$ & СР030707-01 & B & Trans & $\mathrm{M}$ & Ad & E. Aleutian Is. & Umnak Is. & GAT \\
\hline 46 & $\mathrm{x}$ & $\mathrm{x}$ & & CР030707-02 & B & Trans & $\mathrm{F}$ & Ad & E. Aleutian Is. & Umnak Is. & GAT \\
\hline 47 & $\mathrm{x}$ & $\mathrm{x}$ & $\mathrm{x}$ & СР030707-03 & B & Trans & $\mathrm{M}$ & Ad & E. Aleutian Is. & Umnak Is. & GAT \\
\hline 48 & $\mathrm{x}$ & $\mathrm{x}$ & $\mathrm{x}$ & СР030707-04 & B & Trans & $\mathrm{F}$ & Ad & E. Aleutian Is. & Umnak Is. & GAT \\
\hline 49 & $\mathrm{x}$ & $\mathrm{x}$ & $\mathrm{x}$ & CP030707-05 & B & Trans & $\mathrm{F}$ & Ad & E. Aleutian Is. & Umnak Is. & GAT \\
\hline 50 & $\mathrm{x}$ & $\mathrm{x}$ & $\mathrm{x}$ & CA189 (dorsal) [2002] & $\mathrm{N}$ & Trans & $\mathrm{F}$ & Ad & West Coast & Dungeness R., WA & WCT \\
\hline 51 & $\mathrm{x}$ & & & CA189 (mid-lateral) & $\mathrm{N}$ & Trans & $\mathrm{F}$ & Ad & West Coast & Dungeness R., WA & WCT \\
\hline 52 & $\mathrm{x}$ & $\mathrm{x}$ & $\mathrm{x}$ & ATx (dorsal) rep\#1 [2003] & $\mathrm{N}$ & Trans & $\mathrm{M}$ & Ad & Prince William Sd & Chenega & GAT1 \\
\hline 53 & $\mathrm{x}$ & & & ATx (dorsal) rep\#2 & $\mathrm{N}$ & Trans & $\mathrm{M}$ & Ad & Prince William Sd & Chenega & GAT1 \\
\hline 54 & & $\mathrm{x}$ & & AH020524-01 & B & Res & $\mathrm{F}$ & ? & E. Aleutian Is. & Akutan Is. & NR \\
\hline 55 & & $\mathrm{x}$ & & AH020527-03 & B & Res & $\mathrm{M}$ & Ad & C. Aleutian Is. & Amlia Is. & SR \\
\hline 56 & & $\mathrm{x}$ & & AH020604-01 & B & Res & $\mathrm{M}$ & Ad & C. Aleutian Is. & Seguam Is. & SR \\
\hline 57 & & $\mathrm{x}$ & & AH020604-02 & B & Res & $\mathrm{F}$ & ? & C. Aleutian Is. & Seguam Is. & SR \\
\hline 58 & & $\mathrm{x}$ & & АН020610-01 & B & Res & $\mathrm{M}$ & Ad & E. Aleutian Is. & Umnak Pass & NR \\
\hline 59 & & $\mathrm{x}$ & & AH020616-02 & B & Res & $\mathrm{M}$ & Ad & E. Aleutian Is. & Akutan Is. & NR \\
\hline
\end{tabular}




\begin{tabular}{|c|c|c|c|c|c|c|c|c|c|}
\hline 61 & $\mathrm{x}$ & AM010725-03 & B & Res & $\mathrm{M}$ & $\mathrm{Ad}$ & Gulf of Alaska & Trinity Is. & NR \\
\hline 62 & $\mathrm{x}$ & AM010725-04 & B & Res & $\mathrm{M}$ & Sub-Ad & Gulf of Alaska & Trinity Is. & NR \\
\hline 63 & $\mathrm{x}$ & AM010805-01 & B & Res & $\mathrm{M}$ & $\mathrm{Ad}$ & E. Aleutian Is. & Unalaska Is. & NR \\
\hline 65 & $\mathrm{x}$ & AM010825-01 & B & Res & $?$ & $?$ & E. Aleutian Is. & Unalaska Is. & NR \\
\hline 66 & $\mathrm{x}$ & СР020713-01 & B & Res & $\mathrm{F}$ & Juv & E. Aleutian Is. & Unalga Pass & NR \\
\hline 67 & $\mathrm{x}$ & СР020717-01 & B & Res & M & $?$ & C. Aleutian Is. & Samalga Pass & NR \\
\hline 70 & $\mathrm{x}$ & СР020820-02 & B & Res & $\mathrm{F}$ & $?$ & Gulf of Alaska & Shelikof Strait & NR \\
\hline 71 & $\mathrm{x}$ & L11 [1996] & B & Res & $\mathrm{F}$ & Ad & West Coast & Puget Sd & SR \\
\hline 72 & $\mathrm{x}$ & L41 [1996] & B & Res & M & Ad & West Coast & Puget Sd & SR \\
\hline 73 & $\mathrm{x}$ & L77 [1996] & B & Res & $\mathrm{F}$ & Ad & West Coast & Puget Sd & SR \\
\hline 74 & $\mathrm{x}$ & АH020618-01 & B & Trans & $\mathrm{F}$ & $?$ & E. Aleutian Is. & Unimak Is. & GAT \\
\hline 75 & $\mathrm{x}$ & АH020618-03 & B & Trans & M & Ad & E. Aleutian Is. & Unimak Is. & GAT \\
\hline 81 & $\mathrm{x}$ & СР020728-01 & B & Trans & $\mathrm{F}$ & $?$ & E. Aleutian Is. & Umnak Is. & AT1 \\
\hline 82 & $\mathrm{x}$ & GOA [2001] & $\mathrm{N}$ & Trans & $?$ & $\mathrm{Y}$ & Gulf of Alaska & Izembeck Lagoon & GAT \\
\hline 83 & $\mathrm{x}$ & neonate [2000] & $\mathrm{N}$ & Trans & M & $\mathrm{Neo}$ & West Coast & Winchester Bay, OR & WCT \\
\hline 84 & $\mathrm{x}$ & CP030714-01 & B & Trans & $\mathrm{F}$ & Ad & C. Aleutian Is. & Delarof Is. & NEWT \\
\hline 85 & $\mathrm{x}$ & СР030719-01 & B & Res & M & Ad & C. Aleutian Is. & Samalga Pass & NR \\
\hline \multicolumn{10}{|c|}{ 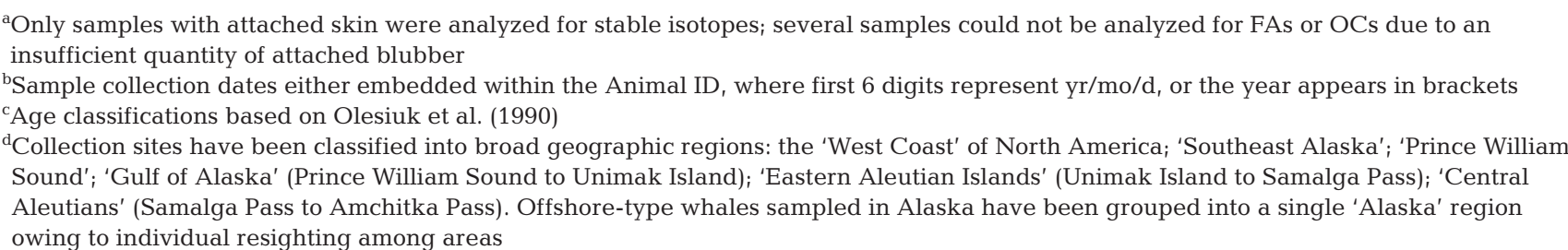 } \\
\hline
\end{tabular}

method involves the following: (1) extraction of approximately 0.5 to $1.0 \mathrm{~g}$ of tissue (mixed with sodium and magnesium sulfates to remove water) by accelerated solvent extraction (ASE) using $50 \mathrm{ml}$ methylene chloride at $100^{\circ} \mathrm{C}$ and 2000 psi; (2) partitioning of the extract into 3 fractions [approximately $46 \%$ for OC analysis, $46 \%$ for total lipid by the standard gravimetric method and $8 \%$ for fatty acid and lipid class (Iatroscan) analyses]; (3) derivatization of the fatty acid fraction to fatty acid methyl esters (FAMEs) using $3 \%$ sulfuric acid in methanol (Iverson et al. 1997); (4) extraction of the FAMEs into iso-octane; (5) drying the extract over a bed of sodium sulfate; and (6) separation and analysis of the FAME extracts on a DB-23 capillary column using quadrupole gas chromatography/mass spectrometry (GC/MS) operated in the selected ion monitoring (SIM) mode. In most cases, the molecular ion was chosen for quantitation, and a confirmation ion was also monitored. Fatty acids C11:1 (as triglyceride) and C13:1 served as surrogate recovery standards added to each sample prior to the ASE solvent extraction and transesterification steps, respectively. A method blank and a $1 \mathrm{~g}$ sample of National Institute Standards and Technology (NIST) fish tissue homogenate standard reference material (SRM 1946) were analyzed with each set of 14 field samples as part of a performance-based quality assurance program. Fatty acid results obtained by the GC/MS method were in excellent agreement with certified and reference values published by NIST for this SRM material. Furthermore, through participation in informal intercomparison exercises with other analytical laboratories, the GC/MS method has been shown to provide results comparable to those obtained using more traditional methods (such as those based on flame ionization, GC/FID). A standard nomenclature system was used for naming these fatty acids, where ' $n$ ' followed by a number refers to the position of the first double bond relative to the alkyl end of the molecule. A full list of all 83 fatty acids measured as part of this study, as well as their abbreviations, and systematic and trivial names can be found in Table 1 of Krahn et al. (2004b).

OC contaminant analyses. Blubber samples (necropsy and biopsy) were analyzed for OC concentrations using the procedure of Sloan et al. (2004). In short, the procedure involves the following: (1) extraction of approximately $1 \mathrm{~g}$ blubber tissue using the same ASE procedure outline above for fatty acids; (2) clean-up of the entire methylene chloride extract on a single stacked silica gel/alumina column; (3) separation of OCs from the 
bulk lipid and other biogenic material by high-performance size exclusion liquid chromatography (HPSEC); and (4) analysis on a low-resolution quadrupole GC/MS system equipped with a $60 \mathrm{~m}$ DB-5 GC capillary column. The instrument was calibrated using a set of 10 multilevel calibration standards of known concentrations. Following this procedure, a total of 40 PCB congeners and 24 chlorinated pesticides were determined in these samples. For a list of all OC contaminants measured by this method, refer to Sloan et al. (2004). In this manuscript, $\Sigma \mathrm{PCB}$ is the sum of all $40 \mathrm{PCB}$ congeners analyzed; $\Sigma \mathrm{D}$ DTs is the sum of $o, p^{\prime}-\mathrm{DDD}, p, p^{\prime}-\mathrm{DDD}, o, p^{\prime}-\mathrm{DDE}, p, p^{\prime}-$ DDE, $o, p^{\prime}$-DDT and $p, p^{\prime}$-DDT; $\Sigma$ chlordanes is the sum of oxychlordane, gamma-chlordane, nona-III-chlordane, alpha-chlordane, trans-nonachlor, and cis-nonachlor; and finally $\mathrm{\Sigma HCHs}$ is the sum of alpha-, beta-, and gamma-hexachlorocyclohexane $(\mathrm{HCH})$ isomers. Total lipid in killer whale blubber samples were measured by either a gravimetric procedure (necropsy samples) (Sloan et al. 2004) or a more sensitive thin layer chromatagraphy flame ionization detection (TLC/FID) method (biopsy samples) (Ylitalo et al. 2004). Individual lipid classes (triglycerides, wax esters/sterol esters, free fatty acids, phospholipids, and sterols) were measured by the TLC/FID method, and their concentrations summed to obtain values for total lipid.

Stable isotope analyses. Killer whale epidermal samples were prepared by (1) freeze-drying the skin overnight in a Virtis Freezemobile 12XL freeze-drier; (2) pulverizing the freeze-dried material to a powder in a micro ball mill; (3) transferring the powder into a $5 \mathrm{~cm}$ diameter glass filter paper folded into a cone, folded shut, and then placing the capsule into a $33 \mathrm{ml}$ ASE cell; (4) extracting lipid using 2 cell volumes of dichloromethane at $25^{\circ} \mathrm{C}$ and 500 psi; (5) removing lipid-free skin from the extraction cell and drying at room temperature in a hood for $10 \mathrm{~min}$; and (6) loading 0.4 to $0.6 \mathrm{mg}$ dried powder into tin cups and combusting in a Costech elemental analyzer attached to a Thermo-Finnigan Delta Plus Isotope Ratio Mass Spectrometer. The values were calibrated against internal laboratory standards (aspartic acid and ${ }^{15} \mathrm{~N}$-enriched histidine), which were analyzed after every 10 samples. Unenriched histidine was also analyzed after every 25 samples as a control material to determine set-to-set reproducibility. For quality control, all standards and the reference material must have standard deviations $\leq 0.3 \%$ for $\delta^{15} \mathrm{~N}$ and $\leq 0.2 \%$ or for $\delta^{13} \mathrm{C}$.

Stable isotope ratios are expressed in $\delta$ notation as per mil (\%o) by the following expression:

$$
\delta Z=\left[\left(R_{\text {sample }} / R_{\text {standard }}\right)-1\right] \times 1000
$$

where $Z$ is ${ }^{15} \mathrm{~N}$ or ${ }^{13} \mathrm{C}$ and $R_{\text {sample }}$ is the ratio ${ }^{15} \mathrm{~N} /{ }^{14} \mathrm{~N}$ or ${ }^{13} \mathrm{C} /{ }^{12} \mathrm{C}$ for the tissue sample. $R_{\text {standard }}$ is the ratio ${ }^{15} \mathrm{~N} /{ }^{14} \mathrm{~N}$ or ${ }^{13} \mathrm{C} /{ }^{12} \mathrm{C}$ of the corresponding standard, atmospheric air and Pee Dee Belemite limestone respectively. The statistical significance of the killer whale grouping differences were calculated using the Tukey-Kramer honestly significant difference (HSD) test at $\alpha=0.05$.

Stable isotope modeling. A diet for each killer whale ecotype was estimated from the literature based on numbers from observed predation events (Ford et al. 1998, Saulitis et al. 2000, C.O.M. unpubl. data 2004). Stable isotope values for all putative prey species listed in Table 6 were gathered from published literature reports, using North Pacific animals when available (Hobson et al. 1997, Ohizumi \& Miyazaki 2001, Satterfield \& Finney 2002, Das et al. 2003b). Only values for whole body, muscle or skin were used. Unfortunately, stable isotope values for steelhead Oncorhynchus mykiss were not available; harbor porpoise Phocoenoides phocoena values were only available from the North Sea rather than the eastern North Pacific.

Models representing calculated $\delta^{15} \mathrm{~N}$ and $\delta^{13} \mathrm{C}$ values $\left(\delta_{\text {model-N }}\right.$ and $\delta_{\text {model-C }}$ respectively) were derived from the literature-based prey diet for each geographic and ecotype group. A model was generated only when sufficient information was available so that a reasonable approximation of the diet could be constructed. It was based on the following equations:

$$
\begin{gathered}
\delta_{\text {model-N }}=\sum_{i=1}^{n}\left(\text { Diet }_{i} \times \delta^{15} \mathrm{~N}_{i}\right)+3.8 \\
\delta_{\text {model-C }}=\sum_{i=1}^{n}\left(\text { Diet }_{i} \times \delta^{13} C_{i}\right)+1.3
\end{gathered}
$$

where $n$ is the number of different prey species consumed; Diet $_{i}$ is the fraction of each prey species based on numbers of animals in the killer whales diet; $\delta^{15} \mathrm{~N}_{i}$ and $\delta^{13} \mathrm{C}_{i}$ are the measured stable isotope ratio values of the $i$ th prey species for nitrogen and carbon respectively; and +3.8 and +1.3 are the applicable isotopic enrichments per trophic level values for nitrogen and carbon respectively (Hobson et al. 1996, 2002). For each killer whale group, the literature-derived stable isotope values for prey were used to compute $\delta_{\text {model-N }}$ and $\delta_{\text {model-C }}$ values for the predator using the estimated diets and Eqs. (2) \& (3) (Table 6). These model values were then directly compared to the measured mean $\delta^{15} \mathrm{~N}$ and $\delta^{13} \mathrm{C}$ stable isotope results of each group to assess the feasibility of their proposed diets.

Statistical analyses. All multivariate and univariate analyses were conducted using JMP Statistical Discovery Software (PC profession edition, version 5.01). Unless indicated otherwise, all univariate comparisons between 2 group means were significance tested $(\alpha=0.05)$ using a 2-sample Student's $t$-test assuming unequal variances. Significant differences among multiple groups having equal variances were evaluated using a Tukey HSD test $(\alpha=0.05)$. When group variances were unequal, significant differences among multiple 
groups were tested instead using the Bonferroni multiple comparisons test (MCT) that corrects for Type 1 errors associated with multiple comparisons and employs a Welch's approximate $t$-statistic to account for unequal variances. All FAME concentration data were expressed on a weight-percent basis (wt\%) by dividing the concentration of each individual FAME by the sum of all FAMEs present in the sample. This is also referred to as the \% composition. Individual PCB congener concentration data were also computed on a wt $\%$ basis and expressed as the concentration of each individual PCB relative to the sum of all 40 PCBs measured. Expression of these data on a wt $\%$ basis effectively normalized the results in such a way that any differences in measured PCB profiles between 2 or more samples represented a difference in the pattern of PCBs present and was independent of absolute tissue concentration. In addition, differences in absolute $\mathrm{OC}$ contaminant exposures were examined by comparing PCB concentrations expressed on a lipid-normalized basis ( $\mathrm{ng} \mathrm{g}^{-1}$ total lipid).

Prior to all statistical calculations, both fatty acid and OC contaminant wt $\%$ data were tested for normality by computing the skew and kurtosis of the individual analyte distributions, and all were found to be moderately non-normal. Neither arcsine nor square-root transformations of these data resulted in a significant improvement in data normality. Therefore, the data were assumed to be robust and parametric statistics applied to the untransformed data.

As an initial means to visualize the overall structure of the fatty acid and OC contaminant results, principal component analyses (PCA) were performed on the wt $\%$ data for each of these 2 analyte classes. PCA of all fatty acid and PCB results were computed on the correlation matrix of the untransformed $\mathrm{wt} \%$ data and the projections of the factor scores of each sample along the first 3 principal component axes (PC1, PC2, and PC3) were computed. All analytes having values below the method quantitation limits in more than $10 \%$ of the samples were excluded from the PCA analysis. Elimination of analytes below quantitation limits reduced the number of fatty acid represented in the PCA plots from 83 to 50 fatty acids and reduced the number of PCB congeners from 40 total measured PCBs to 22 .

Linear discriminant function analysis (DFA) of the fatty acid and OC contaminant concentration data was performed on the untransformed wt $\%$ results using the interactive forward-stepwise method of variable selection. For a relatively large data set, the (-2log-likelihood) value is an asymtopic estimator of the Akaike information criterion (AIC) that is widely applied in statistics for optimum model selection. Thus, the optimum discriminant function models derived were chosen by continuously introducing an additional variable to the model until the (-2log-likelihood) value com- puted for the model changed by less than a value of 1 . All models were validated using a cross-validation method in which one-third of the samples were randomly selected and removed from the data set; a new set of canonical functions were computed based on the remaining two-thirds of the samples, and the classification of the 'unknown' one-third samples was then determined and compared with their known classifications. This process of random-sample elimination, model generation, followed by classification prediction of the eliminated sub-set was repeated 10 times and the misclassification rate of the model was computed.

\section{RESULTS}

\section{Classification of ecotypes by fatty acid analysis}

Prior to fatty acid and OC contaminant analyses, lipid classes were measured in blubber samples to test for indications of decomposition (presence of $>5 \%$ free fatty acids). All biopsy samples listed in Table 1 had free fatty acid concentrations less than $5 \%$. The free fatty acid concentrations in the necropsied blubber samples acquired from the stranded animals, L60, CA189, and ATx, were also quite low ( $2 \%$ or less) indicating decomposition had not occurred in these samples (Krahn et al. 2004b). The FAME weight percent (wt\%) results obtained for the first 53 killer whale blubber samples shown listed in Table 1 were subjected to a PCA analysis to determine whether fatty acids results could be used to separate killer whales by known ecotype (results not shown). Although only marginal separation was observed along the first and second PC axes between the 3 ecotypes, there was sufficient additional separation achieved along the third PC axis to adequately distinguish among animals of these 3 presumed ecotypes in 3-dimensional factor space. The 10 most abundant fatty acids in the outer blubber layers of these whales that are believed to be predominantly endogenous in origin were (in decreasing order of concentration) C18:1n9, C16:1n7, C16:0, C14:0, C18:1n11, C14:1n5, C18:1n7, C16:1n9, C14:1n7, and $\mathrm{C} 14: 1 \mathrm{n} 9$. The 10 most abundant predominantly exogenous 'dietary' fatty acids were (in decreasing order) C20:1n9, C22:1n11, C18:2n6, C20:5n3, C16:4n3, C22:6n3, C16:2n4, C22:5n3, C18:3n3, and C22:1n9.

Killer whale FAME profiles were also analyzed using linear DFA, where the wt $\%$ data for all fatty acids found to be present above the method detection limits $(n=50)$ were input as the covariate variables and the known ecotypes as the categorical values. DFA was performed using the forward step-wise method of variable selection to find a smaller subset of fatty acids (from among all 50) that optimally separated the killer 
whales by ecotype. By using this method of variable selection, no pre-existing a priori assumptions were made about the relative importance of the fatty acids. The 2-dimensional model which best optimized the separation of the 3 ecotypes is shown in Fig. 1. Excellent separation of the 3 ecotypes was achieved using this 5 covariate model based on the proportions of $\mathrm{C} 24: 1 \mathrm{n} 9, \mathrm{C} 16: 1 \mathrm{n} 5, \mathrm{C} 16: 2 \mathrm{n} 6, \mathrm{C} 20: 4 \mathrm{n} 6$, and C20:5n3. The ability of the model to successfully predict ecotype based on the wt $\%$ data for these 5 specific fatty acids was tested using the cross-validation method (see 'Materials and methods'). The misclassification rate was low $(3.3 \%)$, demonstrating that killer whale ecotype can be determined with acceptable reliability from fatty acid analysis of blubber. In further support of using differences in blubber chemistry to corroborate the proposed 3 ecotype hypothesis, significant differences $(p<0.0167$, Bonferroni MCT) among the 3 ecotypes were demonstrated by performing univariate pairwise comparisons for all 50 individual fatty acids. For each of the pairwise comparisons among the 3 proposed killer whale ecotypes, the total numbers of fatty acids exhibiting significantly different mean values were offshores-residents (13/50), offshores-transients (13/50), and residents-transients (17/50).

The mean summed FAME wt $\%$ values $( \pm 1 \mathrm{SD})$ of each class of fatty acids in blubber of each killer whale ecotype are provided in Table 2. Only 4 blubber samples from offshore animals were available, resulting in substantially greater uncertainty in their mean values compared to the other 2 ecotypes. Among the classes of fatty

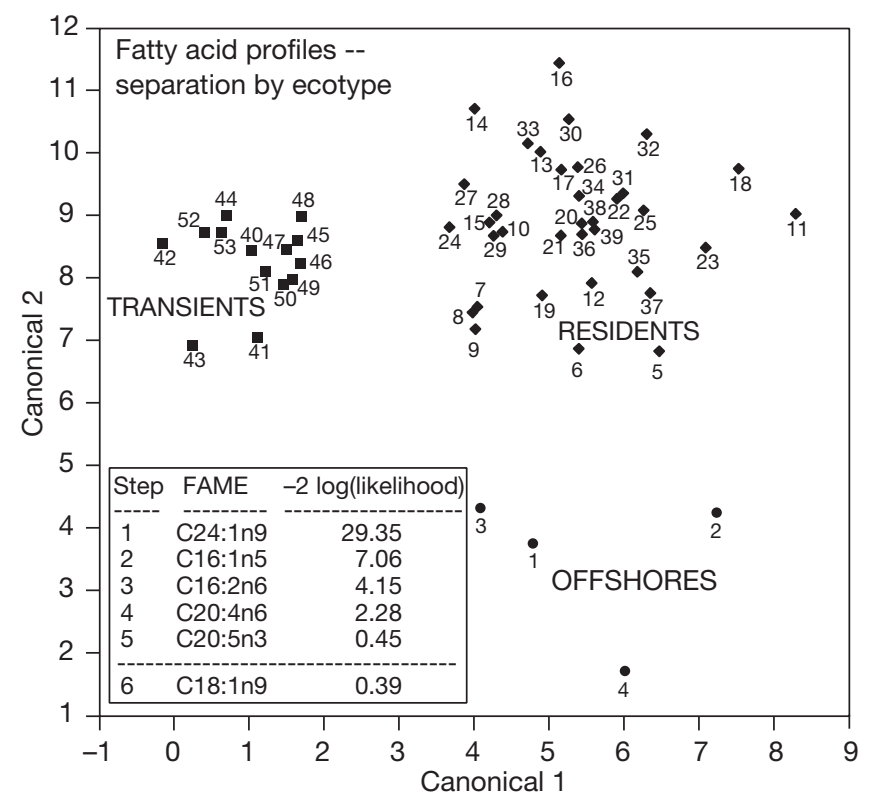

Fig. 1. Orcinus orca. First 2 discriminant functions showing separation of killer whale ecotypes based on fatty acid profiles of the blubber biopsies
Table 2. Orcinus orca. Mean $( \pm 1 \mathrm{SD})$ FAME compositions in resident, transient and offshore blubber biopsy samples expressed in units of percentage of total fatty acids by mass (wt \%). $\Sigma$ SCMU: sum of all short-chain mono-unsaturated fatty acid methyl esters (C $\leq 16)$; $\Sigma$ LCMU: sum of all longchain mono-unsaturated fatty acid methyl esters $(C>16)$. IPUFA: sum of all poly-unsaturated fatty acid methyl esters

\begin{tabular}{|lccc|}
\hline & $\begin{array}{c}\text { Offshore } \\
(\mathrm{n}=4)\end{array}$ & $\begin{array}{c}\text { Resident } \\
(\mathrm{n}=31)\end{array}$ & \multicolumn{1}{c|}{$\begin{array}{c}\text { Transient } \\
(\mathrm{n}=12)\end{array}$} \\
\hline Totals & & & \\
$\Sigma \mathrm{n}-6$ & $2.32 \pm 0.35$ & $1.96 \pm 0.27$ & $1.61 \pm 0.60$ \\
$\Sigma \mathrm{n}-3$ & $4.51 \pm 1.96$ & $3.57 \pm 1.18$ & $2.14 \pm 0.92$ \\
$\Sigma$ saturated & $17.12 \pm 2.49$ & $14.50 \pm 1.99$ & $16.68 \pm 3.78$ \\
$\Sigma$ SCMU & $25.80 \pm 2.74$ & $31.76 \pm 4.00$ & $39.38 \pm 6.36$ \\
$\Sigma$ LCMU & $49.25 \pm 2.39$ & $46.99 \pm 4.19$ & $39.07 \pm 7.58$ \\
$\Sigma$ PUFA & $7.82 \pm 1.91$ & $6.74 \pm 1.42$ & $4.84 \pm 1.83$ \\
$\Sigma$ branched & $1.29 \pm 0.10$ & $1.80 \pm 0.38$ & $2.11 \pm 0.78$ \\
Individual fatty acids exhibiting high relative concentra- \\
tions in pinnipeds/cetaceans & & \\
C14:1n5 & $1.63 \pm 0.82$ & $4.10 \pm 1.11$ & $5.00 \pm 1.07$ \\
C16:1n7 & $17.94 \pm 2.12$ & $21.61 \pm 2.28$ & $25.18 \pm 4.26$ \\
C18:1n9 & $32.72 \pm 0.83$ & $27.26 \pm 2.79$ & $24.45 \pm 4.94$ \\
Individual fatty acids exhibiting high relative concentra- \\
tions in fish & \multicolumn{3}{|c}{} \\
C16:0 & $8.77 \pm 2.31$ & $5.42 \pm 1.02$ & $5.50 \pm 1.34$ \\
C18:0 & $1.71 \pm 0.49$ & $0.94 \pm 0.24$ & $0.93 \pm 0.20$ \\
C22:6n3 & $1.35 \pm 0.96$ & $0.74 \pm 0.40$ & $0.32 \pm 0.20$ \\
C24:1n9 & $0.27 \pm 0.06$ & $0.27 \pm 0.06$ & $0.10 \pm 0.02$ \\
\hline
\end{tabular}

acids listed, all expressed in units of fatty acid methyl esters and compared using the Bonferroni MCT statistical test at the indicated $\mathrm{p}$-value, short-chain mono-unsaturated fatty acids (SCMU) were significantly different $(\mathrm{p}<$ 0.0167 ) among all 3 ecotypes. Large differences in omega- 3 fatty acids were also observed between the ecotypes, with the offshore animals having the highest mean proportion. However, differences in mean omega-3 fatty acid compositions were only statistically significantly different $(\mathrm{p}<0.0167)$ between the resident and transient populations. Transient whales had the highest mean proportions of SCMU and lowest mean proportions of long-chain mono-unsaturated fatty acids (LCMU), omega-3 and poly-unsaturated fatty acids (PUFA) in their outer blubber layers. Although the sums of branched-chain fatty acids were similar between resident and transient whales, the offshore biopsy samples contained consistently lower proportions of branchedchain fatty acids than either the resident whales $(p<0.001)$ or the transient whales $(p<0.005)$. Omega-6 fatty acids were significantly different only between the offshore and transient ecotypes $(p<0.0167)$. The resident killer whale samples had somewhat lower proportions of saturates than were found for either the offshores $(p<0.14)$ or the transients $(p<0.08)$. The mean FAME results for 7 specific fatty acids in these animals are also given in Table 2 . These individual fatty acid results will be combined with stable isotope and $\mathrm{OC}$ results to 
broadly infer the prey preferences of each of the 3 killer whale ecotypes (see 'Discussion').

\section{Classification of haplotypes by fatty acid analysis}

Measurements of the fatty acid profiles of killer whale blubber biopsy samples also allowed killer whales of the same ecotype, but of differing mtDNA haplotypes, to be differentiated. Although an insufficient number of animals with offshore and transient haplotypes were available, samples from a relatively large number of resident animals with 3 known mtDNA haplotypes (denoted SR, NR, NEWR) were available and subsequently analyzed for their fatty acid compositions. In order to minimize the possible effects of large temporal and spatial variations on the ability of the model to categorize these animals by haplotype, only the animals from Alaska collected in 2002/2003 were included in this analysis. The results were subjected to a forward stepwise linear discriminant function analysis using known haplotype as the categorical value. Good separations among the 3 haplotypes were achieved using the optimized model (Fig. 2), which is based on the proportions of 4 covariate variables: C16:1n7, anteiso-C15:0, C16:1n5, and C14:1n7. The prediction success of this discriminant function model was also estimated using the cross-validation technique, and the misclassification rate of this model was deemed to be acceptable at $6.9 \%$.

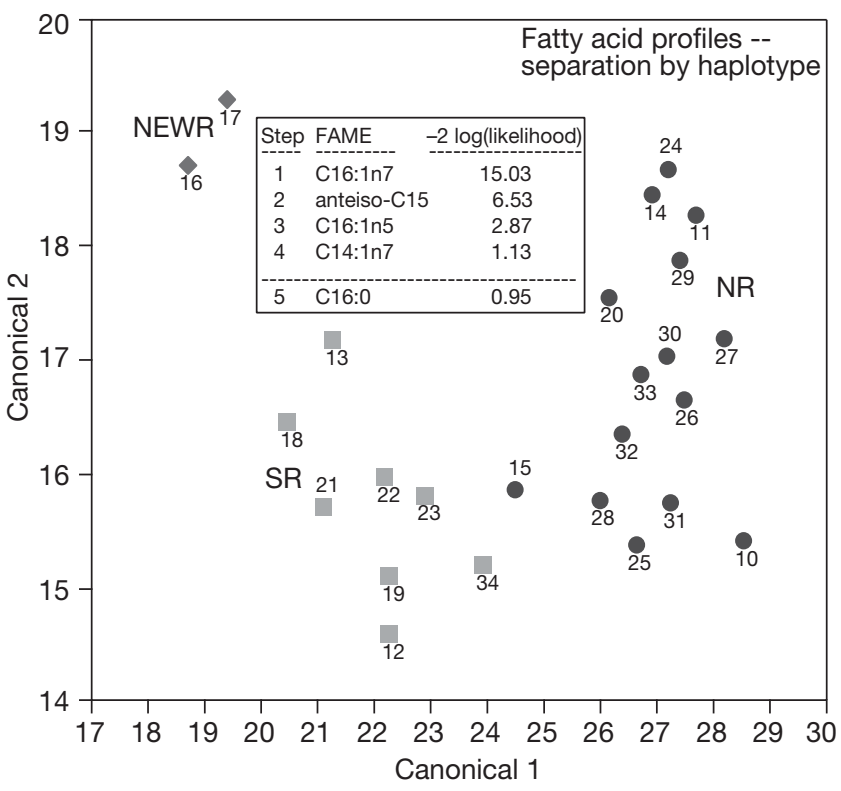

Fig. 2. Orcinus orca. First 2 discriminant functions showing separation of 2002/2003 Alaskan resident killer whales by mitochondrial DNA haplotype from fatty acid profiles of the blubber biopsies where the whales are grouped into 1 of the 3 known resident haplotypes denoted as NEWR, SR and NR

\section{Fatty acid composition of inner blubber necropsy samples}

Fatty acid analysis of near-muscle blubber was only possible for the 3 necropsied animals (L60, CA189 and ATx) in which full depth blubber samples were acquired. As noted above and in Krahn et al. (2004b), the proportion of free fatty acids observed in the blubber of these stranded animals was quite low $(<2 \%)$, indicating that these necropsy samples had not decomposed and therefore would serve well as representative samples for making comparisons to blubber samples acquired by biopsy sampling (see 'Discussion'). Table 3 provides results summarizing the mean wt $\%$ FAME values measured in the inner blubber layers $(>4 \mathrm{~cm})$ of these animals. Proportions of omega-3, LCMU, and PUFA fatty acids were significantly lower in the transient whales than in the resident animal (Table 3). Interestingly, the largest difference in fatty acid composition between resident and transient ecotypes was for SCMU fatty acids, for which it was observed that $\Sigma$ SCMU values were approximately 2.5 times greater in the transient animals. In contrast, omega-6, saturated, and branched-chain fatty acids were not significantly different between the 2 ecotypes. Finally, the mean wt\% proportions of the 7

Table 3. Orcinus orca. Mean ( \pm 1 SD) FAME compositions in the inner (near-muscle) blubber layers of 3 necropsied whales expressed in units of percentage of total fatty acids by mass (wt \%). $\Sigma$ SCMU: sum of all short-chain monounsaturated fatty acid methyl esters $(\mathrm{C} \leq 16)$; $\Sigma$ LCMU: sum of all long-chain mono-unsaturated fatty acid methyl esters (C > 16); LPUFA: sum of all poly-unsaturated fatty acid methyl esters

\begin{tabular}{|c|c|c|c|}
\hline & $\begin{array}{c}\mathrm{L60} \\
\text { (resident) } \\
(\mathrm{n}=4)\end{array}$ & $\begin{array}{c}\text { CA189 } \\
\text { (transient) } \\
(\mathrm{n}=2)\end{array}$ & $\begin{array}{c}\text { ATx } \\
\text { (transient) } \\
(\mathrm{n}=2)\end{array}$ \\
\hline \multicolumn{4}{|l|}{ Totals } \\
\hline$\Sigma \mathrm{n}-6$ & $2.52 \pm 0.02$ & $2.77 \pm 0.09$ & $2.48 \pm 0.09$ \\
\hline$\Sigma \mathrm{n}-3$ & $14.95 \pm 1.14$ & $10.21 \pm 0.70$ & $8.53 \pm 0.49$ \\
\hline ¿saturated & $21.01 \pm 0.38$ & $21.84 \pm 0.96$ & $18.16 \pm 0.03$ \\
\hline$\Sigma \mathrm{SCMU}$ & $10.72 \pm 1.96$ & $26.30 \pm 1.02$ & $27.73 \pm 1.19$ \\
\hline$\Sigma \mathrm{LCMU}$ & $48.75 \pm 0.71$ & $36.58 \pm 1.17$ & $41.58 \pm 0.67$ \\
\hline$\Sigma$ PUFA & $19.40 \pm 1.07$ & $15.21 \pm 0.83$ & $12.39 \pm 0.55$ \\
\hline इbranched & $1.55 \pm 0.09$ & $2.91 \pm 0.16$ & $1.06 \pm 0.00$ \\
\hline \multicolumn{4}{|c|}{$\begin{array}{l}\text { Individual fatty acids exhibiting high relative concentra- } \\
\text { tions in pinnipeds/cetaceans }\end{array}$} \\
\hline C14:1n5 & $0.47 \pm 0.13$ & $2.71 \pm 0.10$ & $3.10 \pm 0.03$ \\
\hline C16:1n7 & $7.67 \pm 1.63$ & $17.46 \pm 0.40$ & $18.86 \pm 0.85$ \\
\hline C18:1n9 & $23.01 \pm 1.03$ & $25.21 \pm 0.62$ & $26.05 \pm 0.01$ \\
\hline \multicolumn{4}{|c|}{$\begin{array}{l}\text { Individual fatty acids exhibiting high relative concentra- } \\
\text { tions in fish }\end{array}$} \\
\hline C16:0 & $8.75 \pm 0.39$ & $7.94 \pm 0.19$ & $6.50 \pm 0.06$ \\
\hline C18:0 & $2.85 \pm 0.41$ & $2.45 \pm 0.07$ & $1.51 \pm 0.05$ \\
\hline $\mathrm{C} 22: 6 \mathrm{n} 3$ & $6.85 \pm 0.68$ & $3.74 \pm 0.33$ & $3.51 \pm 0.47$ \\
\hline C24:1n9 & $0.80 \pm 0.16$ & $0.11 \pm 0.01$ & $0.08 \pm 0.01$ \\
\hline
\end{tabular}


individual fatty acids that are indicative of fish and marine mammal lipids are also provided for each of these whales (Table 3) and will be used to infer the relative contribution of fish and marine mammals to their diets (see 'Discussion').

\section{Classification of ecotypes from blubber PCB patterns}

The PCB patterns of the resident, transient and offshore animals were markedly different from one another and were well separated by PCA in 2dimensional factor space (results not shown). The resident animals were most closely associated with the lower chlorinated PCB congeners, in particular the tetra- and pentachloro-congeners. In contrast, the transient and offshore animals were characterized by higher relative amounts of hexachloro- and heptachloro-congeners respectively in their blubber. These wt \% differences among the 3 ecotypes represented actual shifts in the relative abundance (patterns) of individual PCB congeners present in these animals and were independent of differences in their total OC exposures.

PCB wt\% results for the resident, transient and offshore killer whales were also analyzed by forward stepwise linear DFA in which the known ecotype of each animal was used as the categorical value. The 3 ecotypes were observed to be well distinguished from one another based on the wt $\%$ data of 3 covariate variables (Fig. 3), specifically, PCB 105, 151, and 99. The misclassification rate of this optimized model was also determined by cross-validation and found to be $2.0 \%$.

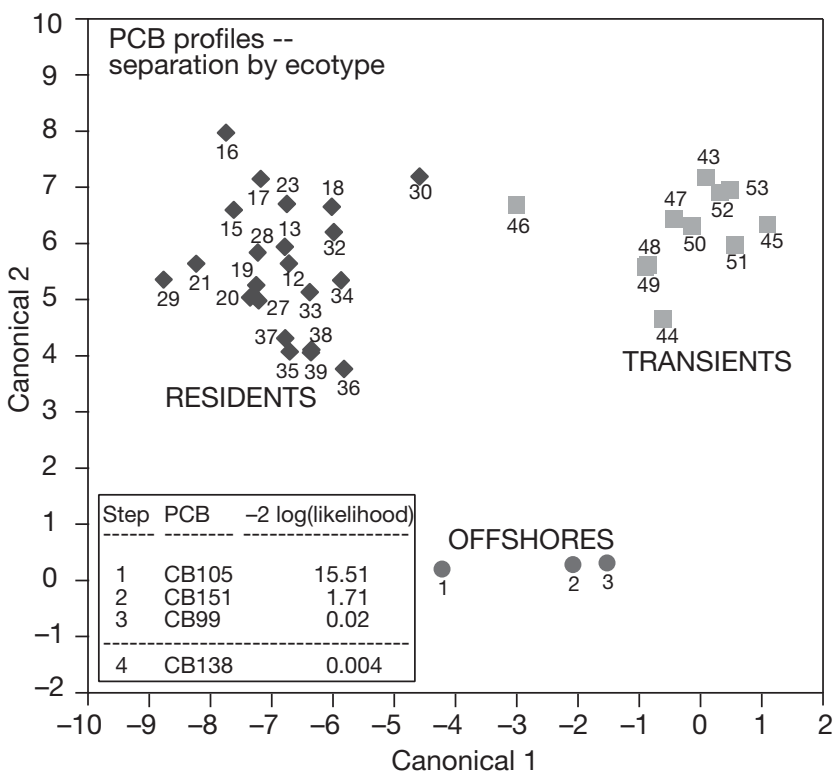

Fig. 3. Orcinus orca. First 2 discriminant functions showing separation of killer whale ecotypes based on the PCB patterns of the blubber biopsies

\section{Stable isotope ratios of North Pacific killer whales}

Stable isotope $\delta^{15} \mathrm{~N}$ and $\delta^{13} \mathrm{C}$ values for killer whales, grouped by region and by ecotype, are given in Fig. 4 and Table 5. Also shown in Fig. 4 are literature-derived stable isotope values for their putative prey. Among the 3 killer whale ecotypes (i.e. taken as groups independent of location), the transient whales were observed to be significantly enriched in ${ }^{15} \mathrm{~N}$ relative to resident animals, whereas offshore-resident and offshore-transient differences were not signifi-

\section{Differences in OC contaminant concentrations among ecotypes}

The mean lipid-normalized concentrations of total PCBs, DDTs, chlordanes, and $\mathrm{HCHs}$ in biopsy samples of adult males for each of the 3 killer whale ecotypes are summarized in Table 4. Results from adult males were used because reproductive females can transfer some of their contaminant burden to their offspring via milk. Concentrations of total PCBs, DDTs, chlordanes and $\mathrm{HCHs}$ were observed to be highest in the transient whales. There were only 2 offshore males, and their PCB and DDT concentrations generally fell between those of the transient and resident whales.
Table 4. Orcinus orca. Lipid-normalized concentrations of organochlorine contaminants expresses as mean $\left(\mathrm{ng} \mathrm{g}^{-1}\right) \pm 1 \mathrm{SD}$ and range (in parentheses) and percent lipid in blubber biopsy samples of Alaskan adult male resident, offshore, and transient whales (includes 2002/2003 Gulf of Alaska, Aleutian Island and Prince William Sound residents and transients, as well as two 2001 offshore animals). Percent lipids measured by either a gravimetric procedure or a TLC-FID method (see 'Materials and methods'). LOD: limit of detection

\begin{tabular}{|lccc|}
\hline$\Sigma$ PCBs & $\begin{array}{c}\text { Residents } \\
(\mathrm{n}=14)\end{array}$ & $\begin{array}{c}\text { Offshores } \\
(\mathrm{n}=2)\end{array}$ & $\begin{array}{c}\text { Transients } \\
(\mathrm{n}=5)\end{array}$ \\
\hline EDDTs & $15000 \pm 6000$ & $66000 \pm 6500$ & $150000 \pm 31000$ \\
& $25000 \pm 10000$ & $170000 \pm 51000$ & $270000 \pm 59000$ \\
& $(10000-35000)$ & $(140000-210000)$ & $(200000-340000)$ \\
chlordanes & $5700 \pm 2200$ & $6600 \pm 6700$ & $72000 \pm 9400$ \\
$\Sigma$ HCHs & $(2700-12000)$ & $(1800-11000)$ & $(57000-81000)$ \\
& $470 \pm 220$ & $120 \pm 170$ & $11500 \pm 3600$ \\
$\%$ lipid & $(200-1000)$ & $(<\mathrm{LOD}-240)$ & $(6300-15000)$ \\
& $10.2 \pm 10.6$ & $16.9 \pm 17.3$ & $17.3 \pm 18.4$ \\
& $(1.2-30)$ & $(4.7-29)$ & $(4.4-26)$ \\
\hline
\end{tabular}



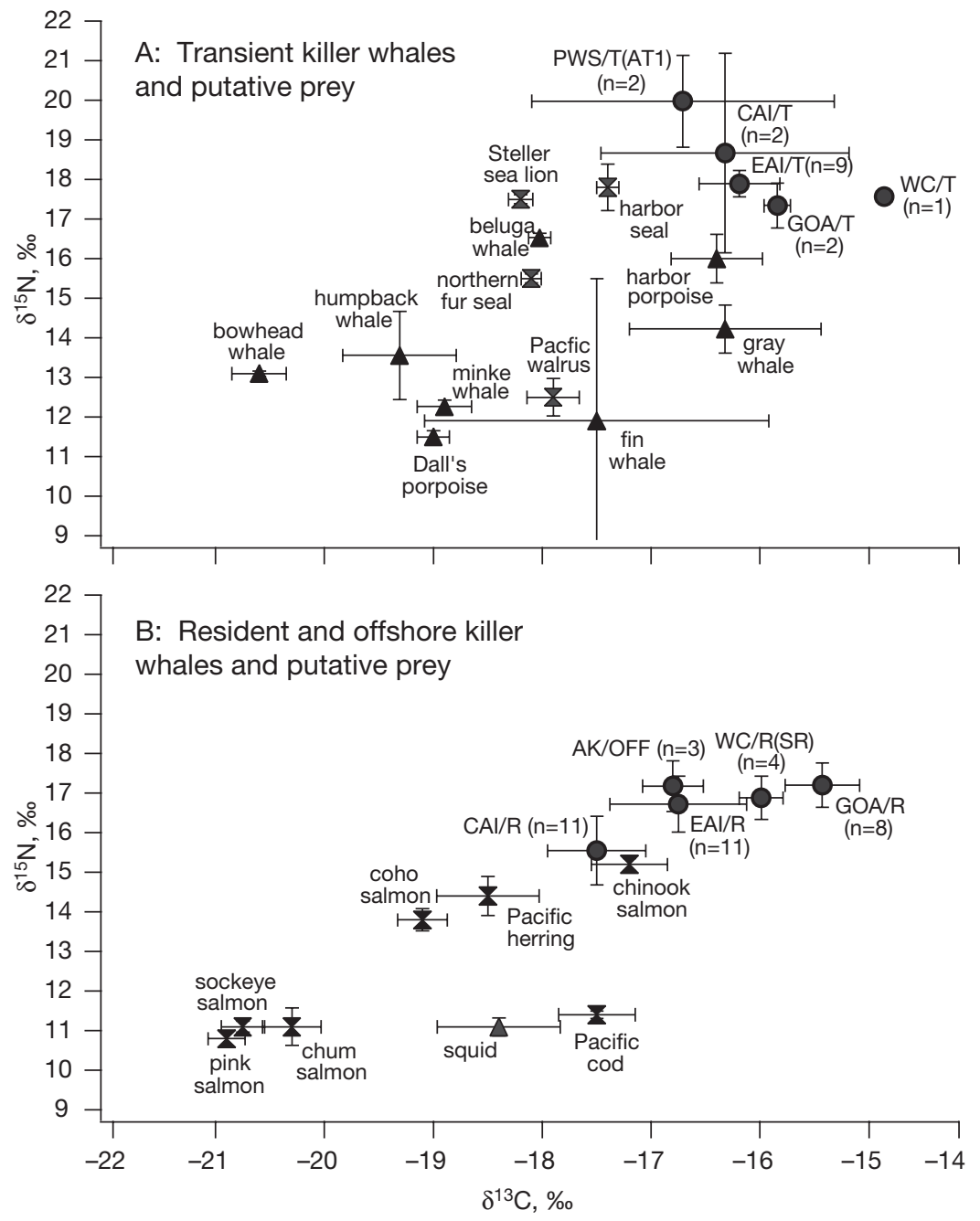

Fig. 4. Nitrogen and carbon stable isotope ratios for killer whale ecotypes (A) transients and (B) residents and offshores and their prey (mean $\pm 95 \%$ confidence intervals). Prey isotope values were taken from the literature. Abbreviations as in Table 5. Sources: beluga whale (Hobson \& Welch 1992, Hobson et al. 2002, Hoekstra et al. 2002); bowhead whale (Schell et al. 1989, Hobson et al. 2002, Hoekstra et al. 2002); fin whale (Gendron et al. 2001, Das et al. 2003b); Dall's porpoise (Ohizumi \& Miyazaki 2001); gray whale (Schell et al. 2000); harbor porpoise (Das et al. 2003a,b); humpback whale (Ostrom et al. 1993, Todd et al. 1997, Schell et al. 2000); minke whale (Ostrom et al. 1993, Born et al. 2003); harbor seal and Steller sea lion (Hobson et al. 1997); Pacific walrus (Hobson \& Welch 1992); northern fur seal (Hobson et al. 1997, Kurle \& Worthy 2002); Pacific cod (Dunton et al. 1989, Hobson et al. 1997); Pacific herring (Kurle \& Worthy 2001); chinook, coho, pink, and sockeye salmon (Satterfield \& Finney 2002); chum salmon (Hoekstra et al. 2002, Satterfield \& Finney 2002)

cant ( $\alpha=0.05$, Tukey HSD). Consequently, unlike fatty acids, simultaneous classification of all 3 killer whale ecotypes cannot be unambiguously determined solely from measured stable-isotope enrichment values of their blubber biopsies. Among the transient whales from all locations, group AT1 transients exhibited the highest ${ }^{15} \mathrm{~N}$ enrichment. The Aleutian Island transient whales (both eastern and central) and the single West Coast transient animal had $\delta^{15} \mathrm{~N}$ values intermediate between those of the AT1 and resident groups. Finally, when comparing adult resident whales to adult transients from similar geographic locations, only the central Aleutian Island transients were significantly more enriched in ${ }^{15} \mathrm{~N}$ relative to their resident counterparts $(\mathrm{p}<0.05,2$-sample $t$ tests); differences between resident and transient whales at all other locations were not significant.

In comparison to nitrogen isotopic enrichment, there were no significant differences ( $\alpha=0.05$, Tukey HSD) in carbon $\delta^{13} \mathrm{C}$ ratios among offshore, resident and transient killer whales when grouped by ecotype (Table 5). When grouped by location, the only notable significant difference in $\delta^{13} \mathrm{C}$ isotope ratios observed in these data $(\alpha=0.05$, Tukey HSD) was for Gulf of Alaska resident whales that were significantly less depleted in ${ }^{13} \mathrm{C}$ than both the eastern Aleutian and the central Aleutian Island residents.

\section{Stable isotope modeling}

The estimated diets of 3 groups of North Pacific killer whales (derived from literature sources) are provided in Table 6 , along with literature $\delta^{15} \mathrm{~N}$ and $\delta^{13} \mathrm{C}$ values for each of the individual prey species comprising these diets. Stable isotope models could only be generated for killer whale groups in which sufficiently quantitative information about their presumed diets were known, as well as stable isotope values for each of the major prey species comprising those diets. This occurred for only 3 of the 10 region/ecotype adult groups listed in Table 5, specifically West Coast residents (WC/R), Gulf of Alaska residents (GOA/R), and the AT1 transients in the Prince William Sound region of Alaska (PWS(AT1)). For each of these 3 groups, the model calculated values for $\delta^{15} \mathrm{~N}$ were observed to be in good agreement with actual measured $\delta^{15} \mathrm{~N}$ values (WC/R: model 17.4, measured 16.9 \pm 0.6; GOA/R: model 17.4, measured 17.2 \pm 0.8 ; PWS(AT1): model 19.5, measured $20.0 \pm 0.8$ ). By con- 
Table 5. Orcinus orca. Mean $( \pm 1 \mathrm{SD})$ stable isotope values for whales grouped by region and ecotype (all adults unless otherwise indicated). AK: Alaska; EAI: Eastern Aleutian Islands; CAI: Central Aleutian Islands; PWS: Prince William Sound; WC: West Coast; GOA: Gulf of Alaska; AI: Aleutian Islands. OFF: offshore; R: resident; $\mathrm{T}$ : transient; AT1: group of transients from Gulf of Alaska/Prince William Sound

\begin{tabular}{|lccc|}
\hline Region/Ecotype & $\mathrm{n}$ & $\delta^{13} \mathrm{C}$ & $\delta^{15} \mathrm{~N}$ \\
\hline AK/OFF & 3 & $-16.8 \pm 0.3$ & $17.2 \pm 0.6$ \\
EAI/R & 11 & $-16.8 \pm 1.1$ & $16.7 \pm 1.2$ \\
EAI/T & 9 & $-16.2 \pm 0.6$ & $17.9 \pm 0.5$ \\
CAI /R & 11 & $-17.5 \pm 0.8$ & $15.6 \pm 1.5$ \\
CAI /T & 2 & $-16.3 \pm 0.8$ & $18.7 \pm 1.8$ \\
PWS/T (AT1) & 2 & $-16.7 \pm 1.0$ & $20.0 \pm 0.8$ \\
WC/T & 1 & -14.9 & 17.6 \\
GOA/R & 8 & $-15.4 \pm 0.5$ & $17.2 \pm 0.8$ \\
GOA/T & 2 & $-15.8 \pm 0.1$ & $17.3 \pm 0.4$ \\
WC/R (Southern & 4 & $-16.0 \pm 0.2$ & $16.9 \pm 0.6$ \\
residents) & & & \\
AI/R juvenile & 1 & -16.5 & 17.9 \\
WC/T neonate & 1 & -15.3 & 21.2 \\
GOA/R subadult & 1 & -14.8 & 21.0 \\
GOA/T yearling & 1 & -15.8 & 19.8 \\
\hline
\end{tabular}

trast, for $\delta^{13} \mathrm{C}$, only the WC/R and PWS(AT1) groups had comparable model versus measured enrichment values (WC/R: model -16.6, measured -16.0 \pm 0.2 ; GOA/R: model -17.6, measured -15.4 \pm 0.5; PWS(AT1): model -16.8, measured $-16.7 \pm 1.0$ ).

\section{DISCUSSION}

The successful classification of eastern North Pacific killer whales by ecotype using a multivariate linear combination of 5 fatty acids measured in blubber biopsies likely resulted from differences in diet, genetics or both among the 3 ecotypes (Fig. 1). For example, fatty acids from ingested prey are transferred with varying degrees of alteration into the adipose tissue of a predator. Therefore, it is likely that the observed ecotype separations were due, at least in part, to differences in their respective diets. However, it is also possible that the observed differences in fatty acid profiles were the result of genetically driven processes, such as selective lipid biosynthesis and metabolism that differentially altered the composition of their fatty acids (GrahlNielsen \& Mjaavatten 1991). Consequently, it is currently unknown whether these 5 specific 'indicator' fatty acids can be used by DFA to successfully classify killer whale ecotypes from other locations that may have substantially differing diets.

PCB patterns in the outer-blubber layers were sufficiently different to likewise allow these whales to be differentiated by ecotype using a linear combination of 3 PCB congeners (Fig. 3). In light of the distinct differences in the presumed diet between the fish-eating resident whales and the mammal-eating transients (Ford et al. 2000), the differing PCB profiles observed in the outer-layer blubber of each killer whale ecotype are

Table 6. Orcinus orca. Comparsions of model isotope values calculated from Eqs. (2) \& (3) (see 'Materials and methods') using prey isotopes from the literatue, and measured (this study: mean $\pm 1 \mathrm{SD}$ ) $\delta^{13} \mathrm{C}$ and $\delta^{15} \mathrm{~N}$ killer whale stable isotope values. Abbreviations as in Table 5. N/A: not available

\begin{tabular}{|c|c|c|c|c|c|c|c|c|}
\hline \multirow{2}{*}{$\begin{array}{l}\text { Region/ } \\
\text { Ecotype }\end{array}$} & \multicolumn{2}{|c|}{ Killer whales } & \multirow[b]{2}{*}{ Prey in diet ${ }^{a}$} & \multirow[b]{2}{*}{ Prey locations } & \multirow{2}{*}{$\begin{array}{l}\text { Prey } \\
\% \text { in } \\
\text { diet }\end{array}$} & \multirow[b]{2}{*}{ Prey $\delta^{13} \mathrm{C}$} & \multirow[b]{2}{*}{ Prey $\delta^{15} \mathrm{~N}$} & \multirow[b]{2}{*}{ Source $^{b}$} \\
\hline & $\begin{array}{c}\delta^{13} \mathrm{C}_{\text {model }} \\
\left(\delta^{13} \mathrm{C}_{\text {measured }}\right)\end{array}$ & $\begin{array}{c}\delta^{15} \mathrm{~N}_{\text {model }} \\
\left(\delta^{15} \mathrm{~N}_{\text {measured }}\right)\end{array}$ & & & & & & \\
\hline $\mathrm{WC} / \mathrm{R}^{\mathrm{c}}$ & $\begin{array}{c}-16.6 \\
(-16.0 \pm 0.2)\end{array}$ & $\begin{array}{c}17.4 \\
(16.9 \pm 0.6)\end{array}$ & $\begin{array}{l}\text { Chinook salmon } \\
\text { Pink salmon } \\
\text { Coho salmon } \\
\text { Chum salmon } \\
\text { Sockeye salmon } \\
\text { Steelhead }\end{array}$ & $\begin{array}{l}\text { S.E. Alaska } \\
\text { S.E. Alaska } \\
\text { S.E. Alaska } \\
\text { S.E. Alaska } \\
\text { S. Alaska } \\
\text { N/A }\end{array}$ & $\begin{array}{l}65 \\
17 \\
6 \\
6 \\
4 \\
2\end{array}$ & $\begin{array}{l}-17.2 \\
-20.9 \\
-19.1 \\
-20.3 \\
-20.8 \\
\text { N/A }\end{array}$ & $\begin{array}{l}15.2 \\
10.8 \\
13.8 \\
11.0 \\
11.1 \\
\text { N/A }\end{array}$ & $\begin{array}{l}1 \\
1 \\
1 \\
1 \\
1\end{array}$ \\
\hline GOA/R & $\begin{array}{c}-17.5 \\
(-15.4 \pm 0.5)\end{array}$ & $\begin{array}{c}17.3 \\
(17.2 \pm 0.8)\end{array}$ & $\begin{array}{l}\text { Coho salmon } \\
\text { Chum salmon } \\
\text { Chinook salmon } \\
\text { Pacific halibut }\end{array}$ & $\begin{array}{c}\text { S.E. Alaska } \\
\text { S.E. Alaska } \\
\text { S.E. Alaska } \\
\text { N/A }\end{array}$ & $\begin{array}{l}92 \\
3 \\
3 \\
2\end{array}$ & $\begin{array}{c}-19.1 \\
-20.3 \\
-17.2 \\
\text { N/A }\end{array}$ & $\begin{array}{l}13.8 \\
11.1 \\
15.2 \\
\text { N/A }\end{array}$ & $\begin{array}{l}1 \\
1 \\
1\end{array}$ \\
\hline PWS/T(AT1) & $\begin{array}{c}-16.8 \\
(-16.7 \pm 1.0)\end{array}$ & $\begin{array}{c}19.5 \\
(20.0 \pm 0.8)\end{array}$ & $\begin{array}{c}\text { Harbor seal } \\
\text { Dall's porpoise } \\
\text { Harbor porpoise }\end{array}$ & $\begin{array}{c}\text { Copper River, AK } \\
\text { N. Pacific } \\
\text { North Sea }\end{array}$ & $\begin{array}{c}56 \\
38 \\
6\end{array}$ & $\begin{array}{l}-17.6 \\
-19.0 \\
-16.4\end{array}$ & $\begin{array}{l}18.6 \\
11.5 \\
16.0\end{array}$ & $\begin{array}{l}2 \\
3 \\
4\end{array}$ \\
\hline \multicolumn{9}{|c|}{$\begin{array}{l}\text { a'See text for literature references providing data used to estimate these dietary preferences. Chinook: Oncorhynchus tshawy- } \\
\text { tscha; pink: O. gorbuscha; coho: O. kisutch; chum: O. keta; sockeye: O. nerka; steelhead: O. mykiss; Pacific halibut: Hippoglus- } \\
\text { sus stenolepis; harbor seal: Phoca vitulina richards; Dall's porpoise: Phocoenoides dalli; harbor porpoise: Phocoena phocoena } \\
\text { b1: Satterfield \& Finney (2002); 2: Hobson et al. (1997); 3: Ohizumi \& Miyazaki (2001); 4: Das et al. (2003 a,b) } \\
\text { 'Prey abundance data for this group represent dietary estimates derived from both northern and southern resident West Coast } \\
\text { populations whereas the measured stable isotope values are for southern residents only }\end{array}$} \\
\hline
\end{tabular}


probably attributable to the largely differing pattern of PCB congeners found present in the tissues of their respective prey. The current study confirmed the results of a previous study (Krahn et al. 2004b) in which fatty acid and PCB profiles of a single Puget Sound resident killer whale were found to be measurably different from those of 2 North Pacific transient animals, but that sample size was too small to be statistically valid.

DFA using a linear combination of only 4 fatty acids also successfully classified Alaskan resident killer whales by mtDNA haplotype (i.e. NR, SR, NEWR) (Fig. 2). In general, resident killer whales in the Aleutian Islands appear to be geographically separated by haplotype (Reeves et al. 2004), with the SR and NEWR haplotypes found west of Samalga Pass at approximately $170^{\circ} \mathrm{W}$ (central Aleutians) and the NR haplotype to the east (eastern Aleutians). Thus, similar to ecotype separation, the ability of fatty acids to differentiate killer whales by haplotype may also be driven primarily by diet and simply reflect differences in the prey available in the central versus eastern Aleutians. For example, Alaskan resident whales with NR haplotype reportedly depredate on longline-caught fish, e.g. sablefish Anaplopoma fimbria and Pacific halibut Hippoglussus stenolepis (Saulitis et al. 2000), and it may be these specific dietary preferences that are responsible for much of the observed differences in the fatty acid profiles among the 3 haplotypes. Alternatively, the haplotype separation, like the ecotype separation, could be the result of genetically driven processes.

Similar to many other marine mammals, blubber fatty acid compositions of killer whales are likely to be appreciably altered relative to ingested fatty acids due to selective metabolism of individual fatty acids prior to deposition in the blubber (Iverson et al. 2004). Consequently, quantitative assessments of killer whale prey preferences will not be possible from fatty acid signature analysis of blubber acquired from either the inner or outer layers unless calibration factors are applied. Moreover, because the inner blubber layer is believed to be more metabolically active than the outer layer (Olsen \& Grahl-Nielsen 2003), and because blubber fatty acids of killer whales are significantly stratified throughout the blubber column (Krahn et al. 2004b), it is the fatty acid composition of the inner blubber layer that is expected to be most similar to that of ingested prey. In spite of these limitations, the results (Tables 2 \& 3) illustrate that key 'indicator' fatty acids may be used to make broad qualitative inferences about diet from both inner and outer blubber biopsy samples.

Although fatty acid profiles vary widely among the fish species, as well as among the marine mammal species that are most likely to be a major part of the diet of killer whales, there is a small subset of characteristic fatty acids that can be used to distinguish fish lipids from marine mammal lipids (Table 3) (Iverson et al. 1997, 2002, Grahl-Nielsen et al. 2003, Olsen \& GrahlNielsen 2003, Krahn et al. 2004b). Most significant among these are the SCMU fatty acids, in particular C14:1n5 and C16:1n7, that are found in very high proportions in marine mammals relative to fish. Also significant are the polyunsaturated omega-3 fatty acids, particularly C22:6n3, that have consistently higher proportions in fish. Comparisons of the inner blubber (necropsy) fatty acid results (Table 3) between resident and transient whales, in relation to the signature fatty acids characteristic of their assumed prey (i.e. marine fish and marine mammals, respectively), indicated that the characteristic fish lipids (C16:0, C18:0, C22:6n3, C24:1n9) were higher in the resident whale, L60; mammal lipids (C14:1n5, C16:1n7, and C18:1n9) were higher in the transients. Qualitatively, these data were therefore consistent with observational data that implicate marine fish as the primary prey source for resident killer whales and marine mammals as the primary source for transients.

Similarly, a comparison of fatty acid results obtained for the inner blubber necropsy samples (Table 3) relative to outer blubber biopsy samples (Table 2) revealed that broad qualitative assessments of killer whale prey can also be made based on measurements of characteristic fatty acids in biopsy blubber. In support of this idea was the observation that qualitative similarity was generally maintained between inner and outer blubber layers for the resident and transient killer whales relative to characteristic fatty acids found at elevated levels in their presumed prey. For example, when the levels of PUFA, omega-3, LCMU, C16:0, C18:0, C22:6n3, and $\mathrm{C} 24: 1 \mathrm{n} 9$ fatty acids in the outer blubber biopsy samples of resident and transient whales were compared (Table 2), most of the same fatty acids that were found elevated in the inner blubber of the resident whale relative to the inner blubber of the transient whales (Table 3) were also found to be elevated in the biopsy samples of residents. Moreover, the levels of C14:1n5 and C16:1n7, which are typically high in tissues of likely marine mammal prey, were higher in the transient killer whales than in the resident whales for both the outer blubber biopsy (Table 2) and inner blubber necropsy samples (Table 3). Thus, several characteristic fatty acids that were acquired via their diets continued to assert a discernable and recognizable influence on the fatty acid compositions of their outer blubber layers. Expressed more simply, a small dietary imprint was retained in the outer blubber tissues of these whales, albeit significantly altered relative both to ingested lipids and to the fatty acid composition of their inner blubber layers.

The offshore whales had fatty acid profiles from biopsy blubber that were most similar to those of the 
fish-eating residents (Table 2). The low relative proportions of $\mathrm{C} 14: 1 \mathrm{n} 5$ and $\mathrm{C} 16: 1 \mathrm{n} 7$ and the high relative proportions of $\mathrm{C} 16: 0, \mathrm{C} 18: 0$ and $\mathrm{C} 22: 6 \mathrm{n} 3$ in the offshore animals suggested that the offshore population is also a major consumer of fish. However, other analyses (discussed below) confounded the fish-eating hypothesis for offshore whales, pointing out the need to consider all results collectively. Unfortunately, many of the longer chain polyunsaturated fatty acids presumed to be dietary in origin (e.g. C20:4n3, C22:4n6, and C20:2n9) had much lower concentrations in these biopsy samples than in the inner-blubber necropsy samples and fell below the method detection limits. Future improvements in analytical sensitivity for these particular fatty acids will likely provide useful additional information about the prey preferences of these whales.

In light of these findings, it is expected that some of the differences observed when comparing fatty acid profiles of biopsy samples from 2 or more killer whales (or killer whale groups) should be qualitatively attributable to differences in their respective diets. An important potential application of this concept is to use fatty acid analysis to detect major temporal shifts in the diets of these top-level predators through periodic biopsy sampling.

In a previous study, Krahn et al. (2004b) showed that, unlike fatty acids, OC contaminants were not highly stratified by depth in the blubber of killer whales and that lipid-normalized OC concentrations in a biopsy sample were a good representation of lipid-normalized concentrations in the entire blubber layer. The significantly elevated levels of lipid-normalized OCs (Table 4) in transient killer whales, compared with residents, can be readily attributed to the transients' predation on higher trophic level marine mammal prey (e.g. harbor seals, Steller sea lions, etc.) and the resulting transfer of high levels of bioaccumulated contaminants from the prey to the predator. In contrast, resident killer whales feed on marine fish that bioaccumulate OCs at much lower levels than do marine mammals (Hoekstra et al. 2003). Although the body burdens of recalcitrant OCs in marine mammals generally increase with age in males (Borga et al. 2004), the large differences observed in the lipid-normalized contaminant concentrations between resident and transient whales (Table 4) were likely driven by OC concentration differences in their predominant prey. Interestingly, PCB and DDT concentrations were higher in the offshore whales than in the residents and began to approach the levels found in the mammal-eating transients, but the sample size for male offshore whales was small (n = 2). The unexpectedly high PCB and DDT concentrations might be due to periodic movements of these offshore whales to areas off the west coast of the continental US, believed to be the southernmost limit of their home range (Matkin et al. 1999), where their prey might be exposed to elevated contaminant levels relative to potential prey in Alaskan waters. Moreover, the ratio $\Sigma D D T s / \Sigma$ PCBs was higher for the offshore whales than for the resident or transient ecotypes. This result further supports the suggestion that offshore whales may visit areas off the west coast of the continental US, in particular California, where DDTs represent a larger proportion of total contaminants than at higher latitudes.

Stable isotope analyses of killer whale epidermis not only allowed the relative trophic levels of the various ecotypes and regionally distinct groups to be directly compared, but these results were also used to provide information about their diets. For example, transient killer whales, as a group, were observed to exhibit a significantly higher trophic level based on $\delta^{15} \mathrm{~N}$ values than observed for the residents (Fig. 4). Furthermore, among the transient whales, individuals from the AT1 population occupied the highest trophic levels. Unexpectedly, the AT1 transient killer whales were substantially more enriched in $\delta^{15} \mathrm{~N}$ than were the Gulf of Alaska transients, even though they share overlapping geographical ranges (Matkin et al. 1999). These dissimilarities in $\delta^{15} \mathrm{~N}$ values among the ecotypes, as well as among animals of the same ecotype but of differing regional habitats, were most likely due to differences in their respective diets. For the AT1 transient whales, the results were consistent with reports indicating that harbor seals comprise a high percentage of their diet, whereas the Gulf of Alaska transients are thought to have a more varied diet (Saulitis et al. 2000, C.O.M. unpubl. data 2004). Finally, the mean $\delta^{15} \mathrm{~N}$ value for the offshore whales was intermediate in value between the group mean values of the residents and transients, perhaps suggesting a mixed diet for the offshores. However, the number of offshore whales analyzed for stable isotopes was small $(\mathrm{n}=3)$, so results from additional offshore whales will be necessary to substantiate their trophic levels relative to the other ecotypes.

Due to the high variability in measured $\delta^{15} \mathrm{~N}$ and $\delta^{13} \mathrm{C}$ values among the 3 killer whale ecotypes (Fig. 4), stable isotopes cannot be used to predict the ecotype of an individual killer whale. However, stable isotope model calculations can be useful in indicating whether dietary estimates derived from direct observations of regionally specific killer whales are consistent with their measured stable isotope values. For example, among resident whales, the published diet for West Coast resident killer whales (Ford et al. 1998), most notably Chinook salmon Oncorhynchus tshawytsche, had modeled carbon and nitrogen values (Table 6) that compared quite well with actual measured values for 
these West Coast whales. In addition, modeled dietary estimates were consistent with measured nitrogen stable isotope ratios for Gulf of Alaska resident killer whales, assuming a fish diet of more than $90 \%$ coho salmon O. kisutch (Saulitis et al. 2000). Although both these models were missing stable isotopes values for steelhead, the contributions of steelhead to the diets of these populations were estimated to be quite low $(\sim 2 \%)$ and therefore should have only a minimal effect on calculated model values. In addition to these 2 resident groups, the diet of AT1 transient killer whales has been reported to consist primarily of harbor seals $(56 \%)$, Dall's porpoises (38\%) and harbor porpoises (6\%) (C.O.M. unpubl. data 2004). Based on this estimated diet, modeled stable isotope values for the AT1 group of transient whales were found to be in excellent agreement with measured AT1 results. Although the stable isotope values for harbor porpoise used in the PWS(AT1) model were derived from animals from the North Sea, and could differ from those in Prince William Sound, harbor porpoises are a relatively small proportion of the total diet and will likely have only a small effect on the calculated model values. In contrast, the $\delta^{13} \mathrm{C}$ values can be considerably affected by geographic (Dunton et al. 1989) and seasonal (Kline 1999) variations. In addition, $\delta^{13} \mathrm{C}$ values can have trophic level enhancements that are highly ecosystem specific. The poorer agreement observed between $\delta^{13} \mathrm{C}$ values (modeled vs. measured) than was observed between $\delta^{15} \mathrm{~N}$ values may be due to these additional sources of variation.

For resident and transient killer whales, results of fatty acid, stable isotope and OC analyses were consistent with the relatively small amount of information known about their dietary habits. Remarkably, there were broad similarities in these chemical signatures of the relatively well-studied resident and transient whales from the eastern North Pacific (e.g. Prince William Sound, Southeast Alaska, British Columbia and Washington State) and the less-studied groups from the western Gulf of Alaska and Aleutian Islands. This suggests that a similar pattern of ecotype-based prey specialization might extend across this wide geographical area. In contrast, results for the offshore whales were contradictory, yet informative. For example, although the fatty acid results obtained for the offshore animals were most consistent with a diet consisting primarily of fish, both the OC and stableisotope results for the offshore whales indicated that marine mammal prey might also be an important part of their diet.

Several speculative, but plausible, alternative diets for the offshore killer whales might reconcile the observed inconsistencies in their fatty acid, stable isotope and $\mathrm{OC}$ results. The first possibility is a fish-based diet containing high proportions of adult coho salmon or Pacific herring Clupea pallasii, both of which are high in total omega-3 fatty acids ( 25 to $35 \mathrm{wt} \%$ ), low in SCMU (Iverson et al. 1997, 2002) and are within approximately 1 trophic level $\left(\delta^{15} \mathrm{~N}+3.8\right)$ of the offshore whales (Fig. 4). Heavy predation by the offshore whales on adult Chinook salmon seems somewhat less likely, because this fish species contains much lower levels of omega-3 ( 15 wt\%) and polyunsaturated fatty acids compared with other putative prey, including other salmonids (Kris-Etherton et al. 2000). As noted above, the unexpectedly high lipid-normalized PCB and DDT concentrations may be due to periodic movement of these killer whales to more southern latitudes within their home range where OC contaminant concentrations in their prey are likely to be elevated. Alternatively, in contrast to the other 2 ecotypes, offshore whales may prey heavily on sharks (Pyle et al. 1999) or other fish that are notably high in omega-3 fatty acids, particularly in the liver (Hornung et al. 1994), high in OCs (Fisk et al. 2002) and occupy intermediate-to-high trophic positions (Fisk et al. 2002). The third, and perhaps least probable, possibility to consider is predation by these specific offshore whales on marine mammals, specifically northern fur seals Collorhinus ursinus because fur seals: (1) are within approximately 1 trophic level of the offshore whales in $\delta^{15} \mathrm{~N}$ and $\delta^{13} \mathrm{C}$ values (Fig. 4); (2) have fatty acid patterns that are different from most other pinnipeds (Heintz et al. 2004) and are somewhat similar to that observed in the offshore whales; and (3) can exhibit intermediate-to-high levels of PCB and DDT contamination (Loughlin et al. 2002). Because relatively few feeding observations have been made for offshore whales, an 'opportunistic diet' comprising both marine fish and marine mammals cannot be ruled out for these Alaskan offshore killer whales in light of the combined fatty acid, OC and stable-isotope results presented here. This interpretation is consistent with observations that killer whales in other parts of the world may be opportunistic feeders (Pitman \& Ensor 2003). However, to our knowledge this possibility is not supported by any direct observations of predation by these eastern North Pacific offshore whales on marine mammals.

The ambiguity in determining the relative importance of marine fish and marine mammals in the diet of killer whales of the offshore ecotype demonstrates the need for caution when interpreting data from any one method as a single indicator of trophic position or when attempting to broadly infer prey preferences. To this end, the current study has shown the value of using multiple independent methods in combination (in particular fatty acid, OC, and stable-isotope analyses of blubber biopsy samples) in assessing the prey preferences of these free-ranging top-level predators. 
Acknowledgements. All killer whale blubber samples were collected under one of the following permits: NGOS NOAA Permit No. 545-1488-03; MMPA Permit No. 782-1510; or NMFS Permit No. 932-1489-05. We thank J. B. Norberg, R. P. Angliss and other members of the Northwest Regional Stranding Network, Marine Mammal Health and Stranding Response Program for sampling killer whales CA189 and L60; Marilyn Dahlheim of AFSC for providing the biopsy samples L11, L41, L77; and R. L. Pitman of Southwest Fisheries Science Center for collecting several additional biopsy samples. We greatly appreciate the technical assistance of D. W. Brown, G. M. Ylitalo, C. A. Sloan, R. H. Boyer, R. W. Pearce and J. L. Bolton in sample and data analysis. We also thank the laboratory staff of the SWFSC Population Identity Program for generating much of the genetic data used in this manuscript, especially K. Coultrup, N. M. Hedrick, A. R. Lang and K. M. Robertson. Finally, we are grateful for the support of T. K. Rowles and the Marine Mammal Health and Stranding Response Program of NOAA Fisheries, as well as the North Pacific Research Board through the US Department of Commerce, NOAA, National Marine Fisheries Service, for providing funding, in part, for this research.

\section{LITERATURE CITED}

Baird RW, Dill LM (1995) Occurrence and behaviour of transient killer whales: seasonal and pod-specific variability, foraging behaviour, and prey handling. Can J Zool 73: 1300-1311

Barrett-Lennard LG (2000) Population structure and mating patterns of killer whales as revealed by DNA analysis. $\mathrm{PhD}$ thesis, University of British Columbia, Vancouver, BC

Barrett-Lennard LG, Ford JKB, Heise KA (1996) The mixed blessing of echolocation: differences in sonar used by fisheating and mammal-eating killer whales. Anim Behav 51: 553-565

Bigg MA (1982) An assessment of killer whale (Orcinus orca) stocks off Vancouver Island, British Columbia. Rep Int Whaling Comm 32:655-666

Borga K, Fisk AT, Hoekstra PF, Muir DCG (2004) Biological and chemical factors of importance in the bioaccumulation and trophic transfer of persistent organochlorine contaminants in arctic marine food webs. Environ Toxicol Chem 23:2367-2385

Born EW, Outridge P, Riget FF, Hobson KA, Dietz R, Øien N, Haug T (2003) Population substructure of North Atlantic minke whales (Balaenoptera acutorostrata) inferred from regional variation of elemental and stable isotopic signatures in tissues. J Mar Syst 43:1-17

Dahl TM, Lydersen C, Kovacs KM, Falk-Peterson S, Sargent J, Gjertz I, Gulliksen B (2000) Fatty acid composition of the blubber in white whales (Delphinapterus leucas). Polar Biol 23:401-409

Das K, Beans C, Holsbeek L, Mauger G, Berrow SD, Rogan E, Bouquegneau JM (2003a) Marine mammals from northeast Atlantic: relationship between their trophic status as determined by $\delta^{13} \mathrm{C}$ and $\delta^{15} \mathrm{~N}$ measurements and their trace metal concentrations. Mar Environ Res 56:349-365

Das K, Lepoint G, Leroy Y, Bouquegneau JM (2003b) Marine mammals from the southern North Sea: feeding ecology data from $\delta^{13} \mathrm{C}$ and $\delta^{15} \mathrm{~N}$ measurements. Mar Ecol Prog Ser 263:287-298

DeNiro MJ, Epstein S (1978) Influence of diet on the distribution of carbon isotopes in animals. Geochim Cosmochim Acta 42:495-506

DeNiro MJ, Epstein S (1981) Influence of diet on the distribu- tion of nitrogen isotopes in animals. Geochim Cosmochim Acta 45:341-351

Dunton KH, Saupe SM, Golikov AN, Schell DM, Schonberg SV (1989) Trophic relationships and isotopic gradients among arctic and subarctic marine fauna. Mar Ecol Prog Ser 56:89-97

Fisk AT, Tittlemier SA, Pranschke JL, Norstrom RJ (2002) Using anthropogenic contaminants and stable isotopes to assess the feeding ecology of Greenland sharks. Ecology 83:2162-2172

Ford JKB, Ellis GM, Barrett-Lennard LG, Morton AB, Palm RS, Balcomb KC (1998) Dietary specialization in two sympatric populations of killer whales (Orcinus orca) in coastal British Columbia and adjacent waters. Can J Zool 76:1456-1471

Ford JKB, Ellis GM, Balcomb KC (2000) Killer whales: the natural history and genealogy of Orcinus orca in British Columbia and Washington State, 2nd edn. UBC Press, Vancouver, BC

Gendron D, Aguiniga S, Carriquiry JD (2001) $\delta^{15} \mathrm{~N}$ and $\delta^{13} \mathrm{C}$ in skin biopsy samples: a note on their applicability for examining the relative trophic level in three rorqual species. J Cetacean Res Manage 3:41-44

Grahl-Nielsen O, Mjaavatten O (1991) Dietary influence on fatty acid composition of blubber fat of seals as determined by biopsy: a multivariate approach. Mar Biol 110: $59-64$

Grahl-Nielsen O, Andersen M, Derocher A, Lydersen C, Wiig O, Kovacs K (2003) Fatty acid composition of the adipose tissue of polar bears and of their prey: ringed seals, bearded seals and harp seals. Mar Ecol Prog Ser 265: $275-282$

Heintz RA, Vollenweider J, Larsen M, Holland L, Lunasin J (2004) Examination of lipid class and fatty acid composition of northern fur seals (Callorhinus ursinus) Part I. Saint Paul animals. NOAA/NMFS, Auke Bay, AK

Hobson KA, Welch HE (1992) Determination of trophic relationships within a high Arctic marine food web using $\delta^{13} \mathrm{C}$ and $\delta^{15} \mathrm{~N}$ analysis. Mar Ecol Prog Ser 84:9-18

Hobson KA, Schell DM, Renouf D, Noseworthy E (1996) Stable carbon and nitrogen isotopic fractionation between diet and tissues of captive seals: implications for dietary reconstructions involving marine mammals. Can J Fish Aquat Sci 53:528-533

Hobson KA, Sease JL, Merrick RL, Piatt JF (1997) Investigating trophic relationships of pinnipeds in Alaska and Washington using stable isotope ratios of nitrogen and carbon. Mar Mamm Sci 13:114-132

Hobson KA, Fisk A, Karnovsky N, Holst M, Gagnon JM, Fortier M (2002) A stable isotope $\left(\delta^{13} \mathrm{C}, \delta^{15} \mathrm{~N}\right)$ model for the North Water food web: implications for evaluating trophodynamics and the flow of energy and contaminants. Deep Sea Res II 49:5131-5150

Hoekstra PF, Dehn LA, George JC, Solomon KR, Muir DCG, O'Hara TM (2002) Trophic ecology of bowhead whales (Balaena mysticetus) compared with that of other Arctic marine biota as interpreted from carbon-, nitrogen-, and sulfur-isotope signatures. Can J Zool 80:223-231

Hoekstra PF, O'Hara TM, Fisk AT, Borga K, Solomon KR, Muir DCG (2003) Trophic transfer of persistent organochlorine contaminants (OCs) with an Arctic marine food web from the southern Beaufort-Chukchi Seas. Environ Pollut 124:509-522

Hoelzel AR, Dahlheim M, Stern SJ (1998) Low genetic variation among killer whales (Orcinus orca) in the eastern north Pacific and genetic differentiation between foraging specialists. J Hered 89:121-128 
Hooker SK, Iverson SJ, Ostrom P, Smith SC (2001) Diet of northern bottlenose whales inferred from fatty-acid and stable-isotope analyses of biopsy samples. Can J Zool 79: 1442-1454

Hornung H, Sukenik A, Gabrielides GP (1994) Distribution and composition of fatty-acids in muscle lipids of inshore fish and deep-water sharks from the eastern Mediterranean. Mar Pollut Bull 28:448-450

Iverson SJ, Frost KJ, Lowry LF (1997) Fatty acid signatures reveal fine scale structure of foraging distribution of harbor seals and their prey in Prince William Sound, Alaska. Mar Ecol Prog Ser 151:255-271

Iverson SJ, Frost KJ, Lang SLC (2002) Fat content and fatty acid composition of forage fish and invertebrates in Prince William Sound, Alaska: factors contributing to among and within species variability. Mar Ecol Prog Ser 241:161-181

Iverson SJ, Field C, Bowen WD, Blanchard W (2004) Quantitative fatty acid signature analysis: a new method of estimating predator diets. Ecol Monogr 74:211-235

Jefferson TA, Stacey PJ, Baird RW (1991) A review of killer whale interactions with other marine mammals: predation to co-existence. Mamm Rev 21:151-180

Kline TC (1999) Temporal and spatial variability of ${ }^{13} \mathrm{C} /{ }^{12} \mathrm{C}$ and ${ }^{15} \mathrm{~N} /{ }^{14} \mathrm{~N}$ in pelagic biota of Prince William Sound Alaska. Can J Fish Aquat Sci 56:94-117

Krahn MM, Ford MJ, Perrin WF, Wade PR, Angliss RP and 6 others (2004a) 2004 status review of southern resident killer whales (Orcinus orca) under the Endangered Species Act. NOAA Tech Memo NMFS-NWFSC-62, Seattle, WA

Krahn MM, Herman DP, Ylitalo GM, Sloan CA, Burrows DG and 5 others (2004b) Stratification of lipids, fatty acids and organochlorine contaminants in blubber of white whales and killer whales. J Cetacean Res Manage 6:175-189

Kris-Etherton P, Taylor D, Yu-Poth S, Huth P, Moriarty K and 5 others (2000) Polyunsaturated fatty acids in the food chain in the United States. Am J Clin Nutr 71:179-188

Kurle CM, Worthy GAJ (2001) Stable isotope assessment of temporal and geographic differences in feeding ecology of northern fur seals (Callorhinus ursinus) and their prey. Oecologia 126:254-265

Kurle CM, Worthy GAJ (2002) Stable nitrogen and carbon isotope ratios in multiple tissues of the northern fur seal Callorhinus ursinus: implications for dietary and migratory reconstructions. Mar Ecol Prog Ser 236:289-300

Loughlin TR, Castellini MA, Ylitalo G (2002) Spatial aspects of organochlorine contamination in northern fur seal tissues. Mar Pollut Bull 44:1024-1034

Matkin CO, Ellis G, Saulitis E, Barrett-Lennard L, Matkin D (1999) Killer whales of southern Alaska. North Gulf Oceanic Society, Homer, AK

Muir DCG, Ford CA, Rosenberg B, Norstrom RJ, Simon M, Beland P (1996) Persistent organochlorines in beluga whales (Delphinapterus leucas) from the St. Lawrence River Estuary - I. Concentrations and patterns of specific PCBs, chlorinated pesticides and polychlorinated dibenzop-dioxins and dibenzofurans. Environ Pollut 93:219-234

Ohizumi H, Miyazaki N (2001) Nitrogen and carbon stable isotope ratios in the muscle of dall's porpoises, Phocoenoides dalli. Proceeding Abstracts 14th Biennial Conference on the Biology of Marine Mammals. Society of Marine Mammalogy, Vancouver, BC, p 160

Olesiuk PF, Bigg MA, Ellis GM (1990) Recent trends in the abundance of harbor seals, Phocha vitulina, in British Columbia. Can J Fish Aquat Sci 47:992-1003

Olsen E, Grahl-Nielsen O (2003) Blubber fatty acids of minke whales: stratification, population identification and relation to diet. Mar Biol 142:13-24

Ostrom PH, Lien J, Macko SA (1993) Evaluation of the diet of sowerbys beaked-whale, Mesoplodon-bidens, based on isotopic comparisons among Northwestern Atlantic cetaceans. Can J Zool 71:858-861

Pitman RL, Ensor P (2003) Three forms of killer whales (Orcinus orca) in Antarctic waters. J Cetacean Res Manage 5: 131-139

Pyle P, Schramm MJ, Keiper C, Anderson SD (1999) Predation on a white shark (Carcharodon carcharias) by a killer whale (Orcinus orca) and a possible case of competitive displacement. Mar Mamm Sci 15:563-568

Reeves RR, Perrin WF, Taylor BL, Baker CS, Mesnick SL (2004) Report on the workshop on shortcomings of cetacean taxonomy in relation to needs of conservation and management, April 30-May 2, 2004, La Jolla, California. Report No. F/SWFSC-363, NOAA Tech Memo, NMFS, US Department of Commerce, Washington, DC

Satterfield FR, Finney BP (2002) Stable isotope analysis of Pacific salmon: insight into trophic status and oceanographic conditions over the last 30 years. Prog Oceanogr 53:231-246

Saulitis EL, Matkin CO, Barrett-Lennard L, Heise K, Ellis GM (2000) Foraging strategies of sympatric killer whale (Orcinus orca) populations in Prince William Sound, Alaska. Mar Mamm Sci 16:94-109

Schell DM, Saupe SM, Haubenstock N (1989) Bowhead whale (Balaena mysticetus) growth and feeding as estimated by $\delta^{13} \mathrm{C}$ techniques. Mar Biol 103:433-443

Schell DM, Rowntree VJ, Pfeiffer CJ (2000) Stable-isotope and electron-microscopic evidence that cyamids (Crustacea: Amphipoda) feed on whale skin. Can J Zool 78:721-727

Sloan CA, Brown DW, Pearce RW, Boyer RH, Bolton JL, Burrows DG, Herman DP, Krahn MM (2004) Northwest Fisheries Science Center procedures for extraction, cleanup and gas chromatography/mass spectrometry analysis of sediments and tissues for organic contaminants. Report No. F/NWC-59, NOAA Tech Memo NMFS, US Department of Commerce, Washington, DC

Springer AM, Estes JA, van Vliet GB, Williams TM, Doak DF, Danner EM, Forney KA, Pfister B (2003) Sequential megafaunal collapse in the North Pacific Ocean: an ongoing legacy of industrial whaling? Proc Natl Acad Sci 100: 12223-12228

Todd S, Ostrom P, Lien J, Abrajano J (1997) Use of biopsy samples of humpback whale (Megaptera novaeangliae) skin for stable isotope $\left(\delta^{13} \mathrm{C}\right)$ determination. J Northwest Atl Fish Sci 22:71-76

Tollit DJ, Steward M, Thompson PM, Pierce GJ, Santos MB, Hughes S (1997) Species and size differences in the digestion of otoliths and beaks; implications for estimates of pinniped diet composition. Can J Fish Aquat Sci 54: 105-119

Ylitalo GM, Yanagida GK, Hufnagle Jr L, Krahn MM (2004) Determination of lipid classes and lipid content in tissues of aquatic organisms using a thin layer chromatography/flame ionization detection (TLC/FID) microlipid method. In: Ostrander GK (ed) Techniques in aquatic toxicology, Vol 2. CRC Press, Boca Raton, FL, p 227-238 